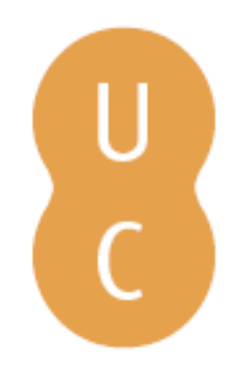

\title{
nombalina
}

\section{O retrato do príncipe como estratégia política e modelo educativo no renascimento}

\author{
Autor(es): $\quad$ Soares, Nair de Nazaré Castro \\ Publicado por: Imprensa da Universidade de Coimbra \\ URL \\ persistente: URI:http://hdl.handle.net/10316.2/32577 \\ DOI: $\quad$ DOI:http://dx.doi.org/10.14195/978-989-26-0442-8_10 \\ Accessed : $\quad$ 26-Apr-2023 10:38:03
}

A navegação consulta e descarregamento dos títulos inseridos nas Bibliotecas Digitais UC Digitalis, UC Pombalina e UC Impactum, pressupõem a aceitação plena e sem reservas dos Termos e Condições de Uso destas Bibliotecas Digitais, disponíveis em https://digitalis.uc.pt/pt-pt/termos.

Conforme exposto nos referidos Termos e Condições de Uso, o descarregamento de títulos de acesso restrito requer uma licença válida de autorização devendo o utilizador aceder ao(s) documento(s) a partir de um endereço de IP da instituição detentora da supramencionada licença.

Ao utilizador é apenas permitido o descarregamento para uso pessoal, pelo que o emprego do(s) título(s) descarregado(s) para outro fim, designadamente comercial, carece de autorização do respetivo autor ou editor da obra.

Na medida em que todas as obras da UC Digitalis se encontram protegidas pelo Código do Direito de Autor e Direitos Conexos e demais legislação aplicável, toda a cópia, parcial ou total, deste documento, nos casos em que é legalmente admitida, deverá conter ou fazer-se acompanhar por este aviso.

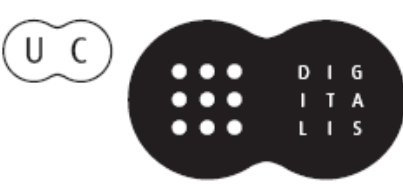


Aurelio Pérez Jiménez, Joșé Ribeiro Ferreira

e Maria do Céu Fialho

(COORdinadores)

\section{Adminiftri Principum.}

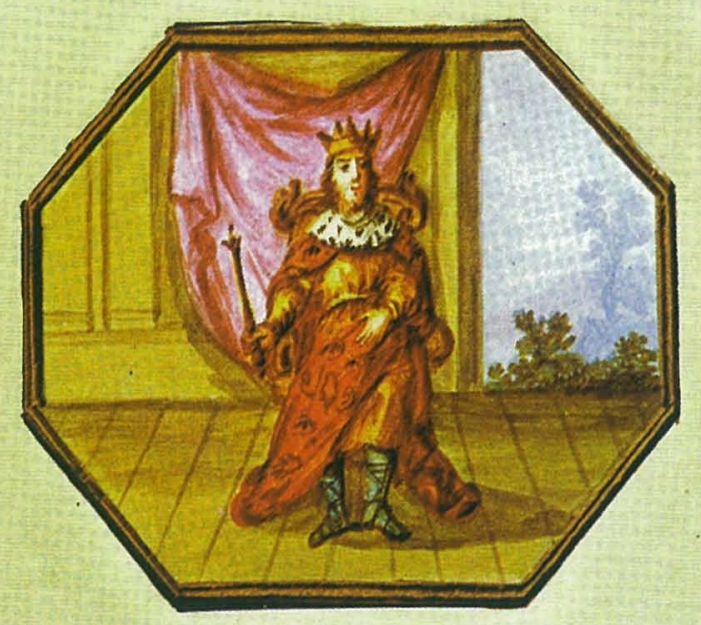

\section{EMBLEM A LIV.}

En tibi plura gerit, quàm lumina prabuit Argos Rex; Aures totidem, quin totidemó, manus. Hec opus Imperio, fidis fupplenda Minijtris, Regi bi funt aures: lumina clara, manus.

\section{- Retrato e a Biografia como estratégia de teorização política}

IMPRENSA DA UNIVERSIDADE DE COIMBRA

Universidad de MálaGa 
(Página deixada propositadamente em branco) 
Aurelio Pérez Jiménez

José RIBEIRo FERREIRA

Maria do Céu Fialho

O RETRATO LITERARIO E A BIOGRAFIA COMO ESTRATÉGIA

\section{DE}

TEORIZACCÃO POLITICA

IMPRENSA DA UNIVERSIDADE DE COIMBRA

UnIVERSIDAD DE MÁlaGa

2004 
Obra publicada com a colaboração de:

Centro de Estudos Clássicos e Humanísticos (Universidade de Coimbra)

International Plutarch Society

Primera edição, Junho de 2004

(c) IMPRENSA DA UnIVERSIDADE DE COIMBRA

(c) Área de Filología Griega. Universidad de Málaga

Coordenação editorial:

Imprensa da Universidade de Coimbra

Área de Filología Griega de la UMA

ISBN: 972-8704-25-9 (PORTUGAL)

ISBN: 84-608-0166-7 (ESPANHA)

Depósito Legal: MA-1420

Impresso em Espanha

Execução gráfica:

IMAGRAF IMPRESORES, S.A.

c/ Nabucco 14

29006 Málaga

Tfno. 952328597

Página de rosto:

"Dos Princepes Transùmptos verdadeiros": Francisco António Novaes Campos, Principe perfeito. Emblemas de D. Joâo de Solórzano. Edição fac-similada do manuscrito da Biblioteca Nacional do Rio de Janeiro oferecido ao Príncipe D. João em 1790 (Prefácio, introdução, comentário e índices por Maria Helena de Teves Costa Ureña Prieto), Instituto de Cultura e Língua Portuguesa, Lisboa, 1985, Emblema LIV, p. 114. 


\title{
O Retrato do Príncipe como estratégia política E MODELO EDUCATIVO NO RENASCIMENTO
}

\author{
Nair de Nazaré Castro Soares \\ Universidade de Coimbra
}

Identificar e definir as coordenadas ideológicas e conceptuais que informam o retrato do príncipe do Renascimento implica conhecer toda a mundividência desta época, na sua vertente de idealização e de realismo político, a partir das obras que desempenharam um papel fundamental na definição do conceito de realeza e do modelo de governante - tarefa tão fascinante como inesgotável.

O processo de evolução espiritual do homem renascentista e as novas experiências culturais e humanas, em que se realiza, participam de todo um conjunto de valores de matriz clássica. Se já o Oriente antigo, o Egipto, a Mesopotâmia, a cultura judaica apresentavam um modelo de governante em certos aspectos não muito diferenciado do da época arcaica grega, é à tradição greco-latina que se prende a imagem do príncipe cristão do século XVI europeu ${ }^{1}$.

A Antiguidade, a partir dos Poemas Homéricos, serve de fonte de inspiração a um modelo de rei e de realeza que vai perdurar no decorrer dos tempos. Nos Poemas Homéricos se descreve a natureza e a missão divina do rei, a par da sua humanidade, que a expressão "pastor de povos" encarna. Pela influência que os

1 Vide Nair de Nazaré Castro Soares, O príncipe ideal no século XVI e a obra de D. Jerónimo Osório, Coimbra, 1994, p. 15-37. fia como estratégia de teorização política, Coimbra-Málaga, 2004, pp. 181-230. 
Poemas Homéricos tiveram, não só a nível da teorização do poder real, mas sobretudo pela espiritualidade e mundo de valores que encerram, devem ser considerados a mais antiga fonte de inspiração do retrato ideal do príncipe ${ }^{2}$.

Também Hesíodo, ao exaltar a virtude e a capacidade operativa do homem, serve de referência quanto aos valores que caracterizam o homem superior.

Sólon surge nos tratados humanistas como o modelo do legislador, que traduz o ideal do rei culto e avisado, capaz de ditar leis e ser ele próprio "lei animada", vó " $\mu \psi \cup \chi O \varsigma^{3}{ }^{3}$ Este princípio, colhido na filosofia helenística, encontra-se formulado, entre nós, desde o direito visigótico, surge na prosa de Fernão Lopes e informa o ideário das representações figurativas, que ilustram as Ordenações régias ${ }^{4}$.

O perfil ideal do chefe político, a Veri principis imago do Renascimento, constrói-se de motivos, ideais e normas de conduta, colhidos em Homero e nos poetas gregos, Hesíodo, Sólon, Teógnis de Mégara, Focílides, Píndaro, Calino e Tirteu; nos autores da tragédia ática, sobretudo Eurípides; nos célebres historiadores da segunda metade do século V a. C., Heródoto e Tucídides — o grande cronista da época de Péricles; nos sofistas, defensores da cultura enciclopédica e artistas da palavra,

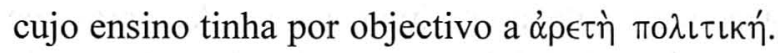

Não sem razão os Espelhos de principes renascentistas citam com frequência estes autores e se servem de passos da sua obra como premissas de argumentação ou como simples trechos que embelezam e dão autoridade ao pensamento exposto. Erasmo, na Institutio principis christiani, cita a cada passo ou transcreve mesmo versos de Homero ${ }^{5}$.

2 Platão, República, 606e-607a, considera Homero educador da Grécia.

3 Este motivo do rei considerado "lei animada", a que se obriga a obedecer, pertence à tradição neopitagórica da fase final da época helenística e encontra-se nos Excerpta que Estobeu conservou.

Sobre a lex Wisigothorum, vide Davide Bigalli, “Justitia' e 'consensus': figure del sovrano nel Cinquecento Portoghese", in Ragione e "civilitas", Figure del vivere associato nella cultura del '500 europeo, dir. J.-C. Margolin et alii, Milano, 1986, p. 96 e sqq., maxime p. 101. Vide e. g. Fernão Lopes, Crónica de D. Pedro I. Com introdução de Damião Peres. Barcelos, 1932: No seu prólogo assim se pronuncia: “ ...ca as leis som regra do que os sogeitos am de fazer e som chamadas prinçipe nom animado e o Rei he prinçipe animado [...] a lei he prinçipe sem alma, como dissemos, e o prinçipe he lei e rregra da justiça com alma" (p. 4-5). Vide Ana Maria Alves, Iconologia do poder real no período Manuelino, Lisboa, 1985.

Vide Erasmi Desiderii Op. omnia (in decem tomos distincta). Recognovit Joannes Clericus, Leiden, 1703. Unveränderter reprographischer Nachdruck. Hildeshein, 1961- 
D. Jerónimo Osório, autor do tratado mais completo de pedagogia política do Humanismo Português, o De regis institutione et disciplina, "Sobre a educação e a instrução do rei", em oito livros, dedicado a D. Sebastião e editado em 1572, faz o retrato do príncipe ideal, de acordo com as funções do rei homérico, sacerdote, orador, juíz e chefe militar ${ }^{6}$. Sendo este tratado um notável exemplo da assimilação da lição clássica à sua mensagem, raramente aduz autoridades antigas e modernas; serve-se, apesar disso, da autoridade de $\mathrm{Hesíodo}^{7}$, de Sólon $^{8}$, de Teógnis de Mégara $^{9}$, de Eurípides ${ }^{10}$.

Ultrapassado o séc. V, em que vigorou a soberania do $\delta \hat{\eta} \mu \circ$, tornaram-se manifestos os inconvenientes deste sistema político. Assim, na primeira metade do séc. IV a. C., assiste-se a um ambiente cultural propício à divulgação da ideia monárquica pelo recurso aos melhores, com base no princípio pitagórico da igualdade geométrica, que leva ao enaltecimento da figura do governante, responsável pelo desenvolvimento da mó $\lambda \iota \varsigma$ e salvaguarda dos interesses dos concidadãos ${ }^{11}$. Tal acontece nas obras de Platão, Aristóteles e Xenofonte.

A literatura da época helenística e os sistemas filosóficos então em vigor, designadamente o neopitagorismo, o neoestoicismo, e ainda o neoepicurismo fomentaram a perspectiva moralizante da problemática política, num regime liderado por

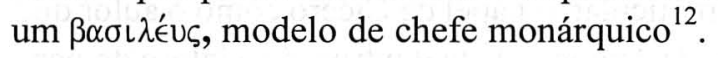

1962 [cit. L B. ]: Od X, v. 305 (L. B. IV. 559-560); Od. IX, v. 345 e sqq. (564 F); Il. II, vv, 24-25 (581 A; 605 C; 606 C); Il. I, v. 231 (575 A); Il. III v. 109 e sqq. (582 F); Il. XV, v. $47(575 \mathrm{~A})$.

6 O De regis institutione et disciplina está incluído no tomo I dos Opera omnia do autor. As citações fazem-se por esta edição e apresentam o tomo, a página e as linhas do texto. H. Osorii Opera omnia, Romae, 1592. Cf. o modelo homérico do regis officium: I. 472. 62-473.33. No De nobilitate ciuili, o Bispo de Silves dirige elogios a Homero (I. 13.3043) e transcreve sequências de versos da Ilíada (I. 12. 3-5 e I. 12. 18-23)

H. Osorii Opera omnia cit. I., 455.54 e sqq.

8

H. Osorii Opera omnia cit. I. 288.12.

H. Osorii Opera omnia cit. I. 440, 16-20.

H. Osorii Opera omnia cit. I. 254. 21-26.

11 J. R. Ferreira, Hélade e Helenos I, Coimbra, 1983, p. 513.

12 G. Aalders, Political thought in Hellenistic times, Amsterdam, 1975, p. 45-48. A. Michel, La philosophie politique à Rome d'Auguste à Marc-Aurèle, Paris, 1969, p. 24 e sqq. A. Michel, "Cicéron, philosophe romain", in Cicéron et Philodème, textes édités par C. Auvray-Assayas et D. Delattre, Paris, 2001, p. 51-60; Marcello Gigante, "Philodème dans l'histoire de la littérature grecque", ibidem, p. 23-50. 
Assiste-se assim, desde a época helenística, a uma soteriologia monárquica e a uma filosofia mística, presentes também nos tratados de política, panegíricos e mesmo composições poéticas dos primeiros séculos do império romano, em que é grande a influência dos estóico-cínicos. Aos reis são concedidos, entre outros, os títulos de inspiração estóica, como pater patriae, parens, invictus, que figuram na terminologia dos tratados medievais e renascentistas. A vulgarização destes conceitos até aos autores cristãos tardios do império revela uma atitude comum com os autores da Antiguidade, no que se refere ao ideal de um governo-providência. São notórias as semelhanças que se podem estabelecer, não só a nível das ideias, mas também da expressão, entre as obras dos autores pagãos e as dos cristãos, no que se refere, por exemplo, à teoria da realeza de direito divino, de inspiração estóica e neopitagórica. Ponto de partida é S. Paulo (Ad Rom. 13, 4 sqq.) a que se seguem autores como Tertuliano (Apol. 30, 32, 33, 36; Ad Nat. 1, 17; Ad Scap. 2), Eusébio de Cesareia, no seu Elogio de Constantino, que inicia a tratadística cristã, e os grandes vultos da Patrística, designadamente santo Ambrósio e santo Agostinho.

Muito embora as origens do pensamento político, que informa esta tratadística cristã, remontem aos autores do séc. IV a. C., a ideologia imperial romana foi a sua fonte mais directa. De salientar, neste particular, o papel de Cícero como o autor que legou a doutrina política ao principado de Augusto. Esta doutrina é a síntese do pensamento helenístico, sobretudo do estoicismo e das teorias da Academia e dos Peripatéticos adaptado por um espírito ecléctico.

A originalidade de Cícero, que fez dele um precursor político, consiste, no entanto, em adaptar a filosofia preexistente aos ideais que fariam, a seus olhos, a história gloriosa de Roma.

Os autores da época imperial foram seguidores da doutrina e mesmo da terminologia ciceroniana ${ }^{13}$.

Através de Cícero, o sistema helenístico do Pórtico, o estoicismo, será, nas gerações futuras, bem representativo do pensamento ético-político antigo. Para tal, além de Cícero, contribuiram de forma significativa ainda outros autores que como ele matizaram de um certo eclectismo filosófico esta doutrina: Séneca, Epicteto e Marco Aurélio - um ministro, um escravo, e um imperador.

13 J. Béranger, Principatus. Études de notions et d'histoire politiques dans l'Antiquité gréco-romaine. Genève, 1975, 117-134 ("Cicéron précurseur politique"). 
Séneca, proclamado cristão por vários padres da Igreja, incluindo S. Jerónimo, que considerou genuína a sua correspondência com S. Paulo, foi um dos principais elos de ligação da cultura medieval com a cultura antiga. O Manual de Epicteto e os Pensamentos de Marco Aurélio teriam a sua principal divulgação no Renascimento ${ }^{14}$.

Nesta época, apesar do pensamento estóico se evidenciar sobretudo no domínio da ética, assimilado à moral cristã, convém recordar também que a sua doutrina está na base da definição do direito natural ${ }^{15}$ — do ius naturale e do ius gentium e sua distinção - que fora objecto da reflexão de S. Tomás e adquiriria o maior significado a partir do séc. XVI e ao longo dos séculos XVII e XVIII.

Entre as principais obras do período imperial romano, em que o retrato do governante se desenha, figuram o De clementia de Séneca - que possivelmente dá origem à expressão "Espelho de Príncipes" (1.1.1) —, onde o preceptor e conselheiro de Nero

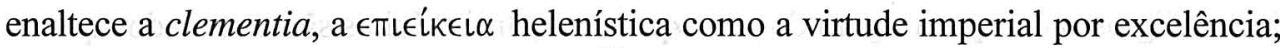
a Historia naturalis de Plínio-o-Velho ${ }^{16}$, a obra histórica de Tácito e ainda o seu Agricola, as máximas do imperador Alexandre Severo; a obra de Musónio, conselheiro de Vespasiano; a vasta produção de Plutarco, autor tão imitado no Renascimento e modelo privilegiado de Erasmo, estética e ideologicamente; a Institutio oratoria de Quintiliano que assimila e desenvolve o programa formativo do orator, praestans uir ciceroniano; as obra de Diógenes Laércio e Valério Máximo, fontes de exempla; a obra do judeu Fílon de Alexandria, sobretudo a sua Vita Mosis, onde Moisés é proposto como modelo ideal de rei; os cinco discursos de Díon Crisóstomo (1-4 e 62), que referem os deveres e os direitos da realeza; o IX discurso de Élio Aristides, dirigido provavelmente a Marco Aurélio, de quem foi conselheiro.

É no entanto no género panegírico, cultivado também por Cícero no Pro Marcello, que encontramos, de facto, a maior divulgação da ideologia política imperial. Um lugar de relevo deve ser dado ao Panegírico de Trajano de Plínio-o-Moço, obra dirigida a um príncipe ainda vivo, onde se apresenta de forma acabada uma doutrinação política, que informa todos os tratados futuros. Justificam

L. Zanta, La renaissance du stoicisme au XVI ${ }^{e}$ siècle, Paris, 1914, réimpr. 1975. Sobre Marco Aurélio, vide Augustin Redondo, Antonio de Guevara (1480?-1545) et l'Espagne de son temps. (De la carrière officielle aux oeuvres politico-morales), Genève, 1976, cap. IX, maxime, p. 467 e sqq. Nachd. 1978-1979: III, p. 77 e sqq.; Cícero, Pro Mil. 10; Phil. 11, 12, 28; De leg. 2. 9. 
a fortuna deste panegírico a universalidade e a intencionalidade da caracterização da figura do príncipe e da sua acção.

As qualidades humanas, exaltadas repetidamente $(2 ; 3 ; 27 ; 28-31)$ definem o príncipe perfeito (castus et sanctus et dis simillimus princeps - 1.3) que, pelos serviços prestados à humanidade (generi humano - 90.1), é uma dádiva dos céus (munus deorum - 1.3).

Esta é, de facto, a visão ideal mesmo dentro do modelo cristão, que ao longo dos tempos se teve do príncipe. Entre nós, o Panegírico de Trajano de Plínio-o-Moço interessou o Infante D. Pedro, que pretendeu vê-lo traduzido "em lingoajem", serviu de modelo a João de Barros, no Panegírico de D. João III e mereceu, pouco depois, em 1541, uma tradução de D. António Pinheiro.

A Idade Média cristã vai estabelecer com contornos mais nítidos os parâmetros ético-religiosos em que a figura do princeps se constrói. Muitos são os tratados que se escreveram para a educação de príncipes ou para a orientação de reis ou de personalidades, no uso de funções governativas ${ }^{17}$. Poder-se-á mesmo dizer que, a par dos Livros de Horas, foram os primeiros manuais de reflexão moral e de formação de leigos.

O carácter formativo destes tratados presidia à intenção primeira da sua elaboração e do seu uso. Essa elaboração era orientada no sentido do enaltecimentro das virtudes cardeais e entre elas a justiça, como a primeira entre todas, e do encorajamento do vigor militar e guerreiro. $\mathrm{O}$ ideal cavaleiresco encontra nestes tratados o seu guia, a expressão acabada do seu código de virtudes.

A partir do séc. $\mathrm{XV}$, a orientação ético-política e militar do governante, a par da definição dos poderes espiritual e temporal, dará lugar a um ambicioso programa intelectual, favorecido pelo exercício e a cultura física, indispensáveis ao rendimento intelectual, ao crescimento harmónico e à saúde do corpo e do espírito, sem serem descurados os preceitos morais, aliados à firmeza da religião. Com os tratados de Pier Paolo Vergerio e Maffeo Vegio, para referir apenas as primícias do género, os Specula principum medievais transformam-se em tratados de educação de príncipes.

Dirigidos a uma determinada personalidade política, num contexto definido, os tratados renascentistas privilegiam a componente pedagógica, que tem por objectivo a formação integral que as litterae humaniores proporcionam, e dão do príncipe um retrato idealizado, apesar de traçado, por decalque, a partir do real. É nestes ter-

Vide Nair de Nazaré Castro Soares, O príncipe ideal no século XVI cit., p. 38-96. 
mos tradicionais que a imagem do governante no Renascimento se ilumina, se decora. No entanto, a teorização política tradicional, clássica ou medieval, adquire a cada passo oportunidade, no espaço e no tempo em que se actualiza. É esta uma das características dos tratados do humanismo renascentista: mesmo quando versam um tema tradicional, ou mesmo um topos, como o do rei e do tirano, enroupam-no de elementos actuais da realidade histórica e vivencial.

Alguns aspectos importantes, todavia, ligam a tratadística do humanismo renascentista à produção anterior. É que, no decurso de longos períodos, as ideias evoluem lentamente. Se é impossível encerrar dentro de regras fixas o fervilhar das ideias novas que se defrontam (ou equacionam de forma diferente ou paralela) com o espírito medieval, numerosas são as perspectivas que reflectem uma continuidade de pensamento ou uma mera repetição de lugares comuns, transmitidos inconscientemente de autor em autor.

Sucedem-se no séc. XVI - algumas delas já iniciadas no séc. XV — as edições das obras de autores gregos, sobretudo da época helenística, de autores latinos, de panegiristas do período imperial e cristão, de autores medievais na língua original ou em tradução.

A par das edições individuais, generaliza-se a edição de colectâneas, que englobam, com intenção pedagógica, obras destes autores antigos e de modernos, que versam uma temática afim.

O conhecimento que os nossos tratadistas têm destes autores é revelado por Frei António de Beja, na Breve doutrina e ensinança de príncipes, que se exprime nestes termos ${ }^{18}$ :

... e de Carolo Magno, rey de França, leemos que foy muyto estudioso em as obras de Sancto Augostinho, e ouve por mestre Alcuíno, monge, de quem aprendeo logica, rhetorica e verdadeira astrologia; e ho emperador Costantino, como escreve meu padre Hieronimo, em ho Livro dos Illustres Varôes, deu a Crispo, seu filho, por mestre e ensinador, ho divino Lactâncio Firmiano; e ho cruel Nero escolheo por seu doutor e mestre, ho sabio Seneca, ho qual antre outras obras dignas de louvor, por causa de Nero, escreveo hũ livro De clemencia que, segundo elle, deve reluzir muyto em os princepes". (...) "E assy pareçe que ho rey, se quer ser feyto illustre e claro ha de ser sabio ou teer tal doctor e mestre per que seja feyto sabio...

18 Fr. António de Beja, Breve doutrina e ensinança de príncipes. Reprodução fac-similada da edição de 1525. Introdução de de M. Tavares Dias, Lisboa, 1965, p. 128. 


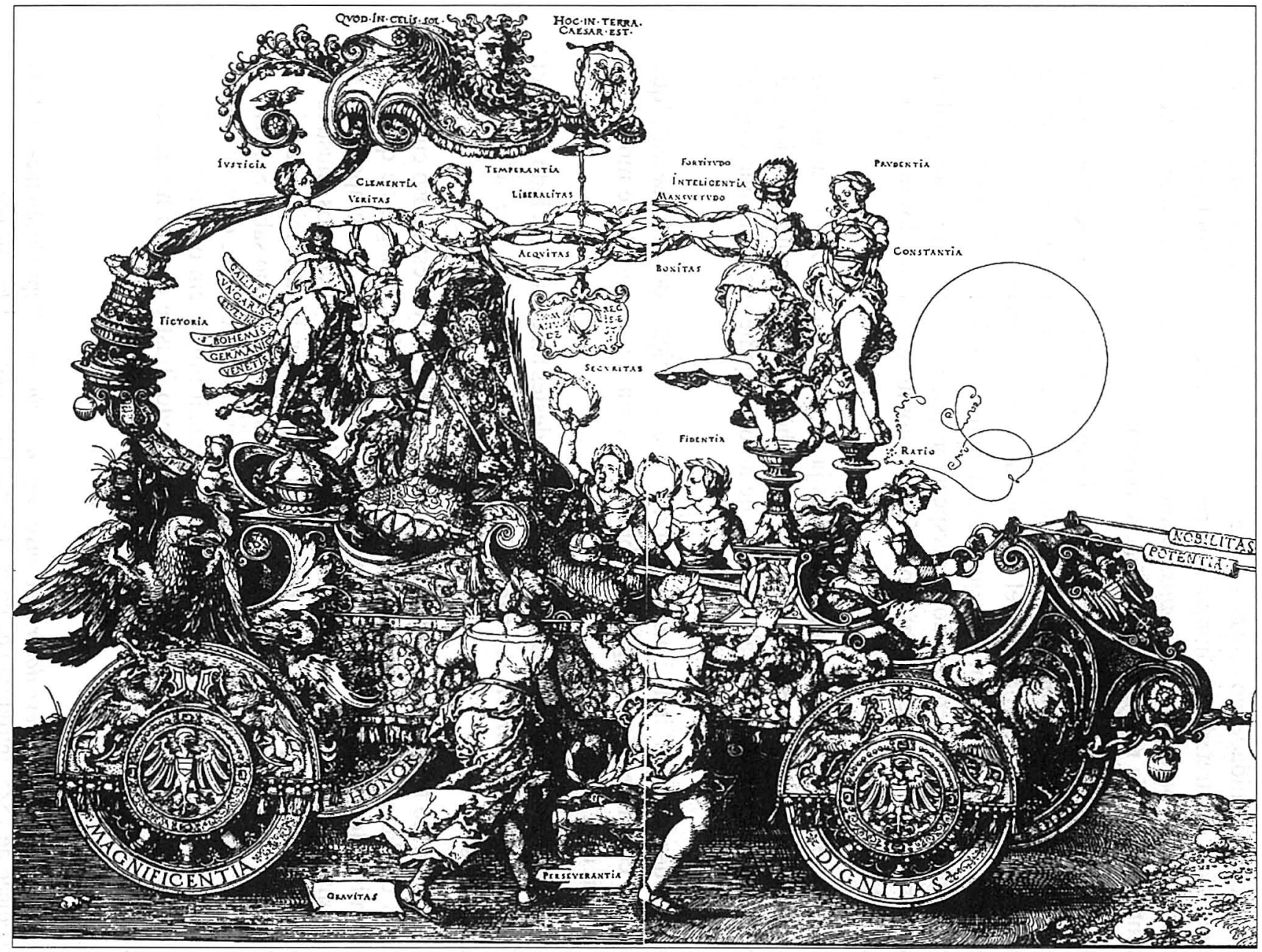

Albrecht Dürer, "O grande carro Triunfal de Maximiliano I", gravura de 1522 (1518) 
Representativo do retrato ideal do príncipe no Renascimento é o desenho preparatório do Grande carro Triunfal de Maximiliano I, Imperador da Alemanha, da autoria de Dürer, que pode considerar-se, na terminologia de Roman Jackobson, a tradução intersemiótica da vasta literatura ético-política da época.

O interesse historiográfico desta composição de Dürer, destinada a exaltar o imperador, não se cinge à simples figuração de cenas autênticas ou de acontecimentos com exactidão histórica, que lhe conferem valor documental. Por detrás da iconografia conceptual está um substrato ideológico, filosófico-político, revelador das ideias e sentimentos da época, que anima toda a imagética e projecta luz sobre muitos aspectos constantes e relevantes da imensa literatura, designada genericamente por Specula principum ${ }^{19}$.

Muito embora não tenha que ver directamente com Portugal, nem com os seus príncipes, esta composição artística apresenta-nos, na figura de Maximiliano $\mathrm{I}^{20}$ bisneto de D. João I e trisavô, por via materna e paterna, de D. Sebastião — o ideal do príncipe cristão do Renascimento, que é de todos os países e de todos os povos, universal como a própria obra de arte.

A imagética renascentista e o seu significado ideológico surgem nesta representação com admirável finura, no mais pequeno pormenor. As rodas do majestoso carro de Maximiliano I são a magnificentia, a honor, a dignitas, a gloria ${ }^{21}$. O impe-

Vide a reprodução do desenho preparatório do Grande carro Triunfal de Maximiliano, supra, p. 188.

20 Maximiliano I, com todos os atributos do poderio político - vide em Wilhelm Waetzolt Dürer and his time, New York, 1950, p. 188, a observação curiosa sobre a forma como Dürer caracterizou a figura do Imperador, de acordo com o Corpus Ivris Justinianeu —, é representado de maneira suficientemente indeterminada, excepção feita para a enumeração das suas vitórias, o que dá ao seu tipo iconográfico um valor universal, que permite identificá-lo com qualquer príncipe cristão.

Sobre o carácter alegórico do Grande carro triunfal de Maximiliano I e seu significado são elucidativas as legendas em latim contidas no desenho preparatório desta obra - "Dürers Holzschnitt des Triumphwagens Kaiser Maximilians I. Wien, K. K. Hofbibliothek" que figura no artigo de K. Giehlow, "Dürers Entwürfe für des Triumphrelief Kaiser Maximilian I, im Louvre. Eine studie zur Entwicklungsgeschichte des Triumphzuges" Jahrbuch der Kunsthistorischen Sammlungen des allerhoechsten Kaiserhauses, XXIX, fasc. 1, Wien, 1910, fig. 18. Faz-se também a descrição dos cavalos e as virtudes que os acompanham, que não correspondem às que figuram no Carro Triunfal definitivo, onde a entourage do imperador se fez representar - facto revelador das influências políticas que se impõem à inspiração e à concepção artísticas (vide Erwin Panofsky, The life and art of Albrecht Dürer, New Jersey, 1955, p. 180-181. 
rador surge rodeado de figuras femininas, assentes sobre colunas, nos quatro ângulos do carro: são as virtudes cardeais ${ }^{22}$, Iustitia, Temperantia, Fortitudo, Prudentia, de mãos interligadas por coroas, entretecidas de folhagem, representativas de muitas outras virtudes que, com elas se interpenetram, lhes especificam e valorizam os conceitos. Entre a Iustitia e a Clementia está a Veritas, que reforça mais ainda a distância do modelo proposto por Maquiavel.

O verdadeiro sentido desta representação encontra-se nas seguintes palavras da Doutrina de Lourenço de Cáceres ao Infante D. Luis exemplificativas da presença constante, nos tratados portugueses da época, das virtudes cardeais, definidoras do ideal de perfeição de um principe cristão ${ }^{23}$ :

E porque dixe bons costumes nam serem al, que virtudes guardadas, he de saber, que ainda que muitos Philozophos, principalmente os Estoycos, assi as punham por fuzis encadeadas, que huma nam possa estar, sem muitas; assentado estaa de quatro, que sam principaes Prudencia, Temperança, Justiça, Fortaleza...

A Victoria, na representação de Dürer, qual Vitória de Samotrácia, transporta nas asas os nomes dos povos dominados e cobre com uma grinalda a cabeça do imperador $^{24}$. O pormenor histórico das vitórias de Maximiliano, integrado no conjunto alegórico, demarca esta composição artística do ideal irenista de Erasmo - que compusera a Institutio principis christiani para o neto deste imperador, Carlos V, esperança de paz no mundo conturbado de guerras - e aproxima-o dos Triunfos dos imperadores romanos, que o espírito festivo do Renascimento faz ressurgir ${ }^{25}$.

O atributo Semper Inuictus, criticado por Erasmo na sua Institutio principis christiani $^{26}$, encontra paralelo na pena do doutor Vasco Fernandes de Lucena, que qualifica

A representação alegórica de conceitos abstractos de idêntica natureza encontra-se já nos arcos imperiais romanos, que inspiram os motivos iconográficos renascentistas (vide $\mathrm{H}$. P. L' Orange, Art forms and civic life in the Late Roman Empire. Princeton, 1965).

Cf. Filozofia de principes apanhada das obras de nossos portugueses por Bento Jozé de Sousa Farinha, 3 vols., Lisboa, 1786-1790: I, p. 40-41.

Entre as virtudes do imperador romano, a uictoria ocupava um papel preponderante. O imperador devia ser Semper Augustus e Semper Inuictus, pelo que a estátua Victoria Augusti, que materializava esta virtude se revestia do maior significado. Cf. M. P. Charlesworth, "The virtues of a roman emperor. Propaganda and the creation of belief", $P B A, 23$ (1937), 105-133.

Vide e. g. Jean Jacquot (ed.), Les fêtes de la Renaissance, 3 vols. Paris, 1956-1975. 
D. João I de muito virtuoso, e nunca vensido, em carta ao infante D. Pedro que the havia pedido vertesse em nossa lingoagem hũa oração de Plínio dos louvores de Cesar ${ }^{27}$.

A consciência da superioridade imperial portuguesa e da missão religiosa e civilizadora da raça lusa, que transparece também de forma clara nos tratados didácticopolíticos da época ${ }^{28}$, dá relevo especial a este tópico, pelo que o Grande carro triunfal de Maximiliano I, no que se refere às vitórias — obtidas sempre por "guerra justa" poderia ser, mutatis mutandis, o de um príncipe português do Renascimento.

Outras virtudes ajudam com a mão a marcha do carro, Grauitas, Perseuerantia, Securitas, Fidentia e outras ainda seguram o freio de cada cavalo.

O condutor do carro é a Ratio, que detém as rédeas, nobilitas e potentia, a força do poder unida ao vigor da virtude ${ }^{29}$.

Todas as figuras e elementos descritos que integram este carro triunfal são exemplificativos do modelo de príncipe no Renascimento europeu, Veri principis imago. Esta frase, colocada junto ao dossel, no desenho preparatório de Dürer, pela sua posição e dimensão dos seus caracteres, figura como uma divisa, que serve de título a toda a composição. Note-se que é esta "imagem do príncipe bom" que Erasmo, na dedicatória ao futuro Carlos V da sua Institutio principis christiani se preocupa em oferecer a todos ${ }^{30}$. Aliás esta preocupação é constante ao longo da sua obra, onde a imagem do verdadeiro príncipe, imagem do próprio Deus, é tida como objectivo máximo ${ }^{31}$.

Uma outra divisa figura, nesta composição alegórica, suspensa em medalhão, do dossel do carro de Dürer - In manu Dei cor regis est. Situada em frente do imperador Maximiliano é bem significativa do desvelo da providência divina para com o poder real. Esta expressão bíblica, que se encontra na obra de Santo Ambrósio e S.

Vide Livro dos ofícios de Marco Tullio Ciceram, o qual tornou em lingoagem o Infante D. Pedro. Edição crítica, prefácio, notas por Joseph M. Piel, Coimbra, Acta Vniversitatis Conimbrigensis, 1948, p. XLII, fol. 68r-68v. Cf. a transcrição do passo infra, p. 278-279.

Vide, e. g. . Doutrina de Lourenço de Cáceres ao Infante D. Luiz, in Filosofia de príncipes, cit., cap. IV, p. 12-13; Jerónimo Osório, De regis institutione et disciplina, lib. IV, Opera omnia, Romae, 1592: I, 438, 60 - 439. 10.

Platão, no Fedro (274 e sqq.) também entrega ao auriga as rédeas da parte racional da alma.

30

Erasmi Desiderii $L B, I V, 559-560$.

31 Erasmi Desiderii $L B$, IV, 569 B; 571 D; 573 D; 584 B. 
Tomás $^{32}$, foi assimilada pelo pensamento humanista. Está presente, elaborada e adaptada ao ritmo poético, na tragédia política Ioannes Princeps de Diogo de Teive, numa fala de $\mathrm{D}$. João III, dirigida à rainha Catarina, e no Colloquium de uita aulica et priuata de Luísa Sigeia ${ }^{33}$.

Assim nos é revelada, figurativa ou literariamente, toda uma cosmovisão, onde a moral tem o seu império. Era ela a base e o fundamento da vida política e a política era entendida como dependente da moral ${ }^{34}$. Reconhecia-se a maior importância ao factor humano, à liderança personalizada em individualidades de carácter exemplar, de cujo comportamento se fazia depender o destino dos povos.

Será necessário avançar até aos princípios do século XVI para Maquiavel dar em Il principe o primeiro e rude golpe nesta tradição ${ }^{35}$.

Em Portugal, praticamente toda a produção literária do séc. XVI nos informa do ideal ético-político: os tratados de educação de príncipes, as obras de carácter jurídico, a produção dramática e poética, as novelas de cavalaria, as crónicas, os panegíricos, para não falar já das orações de aclamação ou em louvor de reis e príncipes, as orações de sapiência - sobretudo as que são posteriores à mudança da Universidade para Coimbra e à fundação do Colégio das Artes - mesmo os tratados de retórica ${ }^{36}$.

A elaboração teórica do modelo de governante no Humanismo renascentista português não é alheia às novas concepções filosóficas do mundo, do direito e do esta-

S. Tomás de Aquino, De regimine principum, cap. VI (ed. de Frère Marie Martin-Cottier, Du royaume-De regno, Texte traduit et présenté. Paris, 1946, p. 63), apoia-se nesta sentença de Salomão (Prov. XXI, 1).

Vide Nair de Nazaré Castro Soares, Tragédia do príncipe João de Diogo de Teive. Introdução, texto, tradução e notas. Coimbra, ${ }^{2} 1999$, p. 150, vv. 104-105: "Nostra ille corda, ceu manu recondita, /custos benignus seruat..."

$\mathrm{Na}$ Antiguidade Clássica, a moral e a política eram indissociáveis (vide, e. g., D. EARL, The moral and political tradition of Rome. London, 1967, p. 17-19; P.-A. Janet, Histoire cit., que se estende da Antiguidade Oriental, grega e latina, através da Idade Média até ao Renascimento e Reforma). Este compromisso existente entre a política e a moral, que perdurou desde a Antiguidade até ao séc. XVI, vai sofrer o primeiro abalo com Maquiavel e com a doutrina da razão de estado dele decorrente.

Para uma análise do retrato do príncipe de Maquiavel, sua fortuna e sua contestação, vide Nair de Nazaré Castro Soares, O príncipe ideal no século XVI cit., p. 198-208.

36 Vide Nair de Nazaré Castro Soares, O príncipe ideal no século XVI cit., p. 167-184; 222-288. 
do $^{37}$ e prende-se também necessariamente com a nossa realidade histórica. Esta é, pode afirmar-se, a principal marca de originalidade do modelo de príncipe no Humanismo português. Vivia-se então a época gloriosa da nossa expansão no mundo. A independência nacional, bem firmada numa monarquia que nem guerras nem lutas religiosas punham em causa ${ }^{38}$, contribui para a formação do ideal herói$\operatorname{co}^{39}$ dos nossos homens de Quinhentos. A par dessa ideia de grandeza - que o cidadão comum, a burguesia endinheirada e a nobreza nutriam na alma - subsistia uma perfeita coesão de um povo, favorecida pelo alto conceito de pátria ${ }^{40}$.

O monarca era sentido como o símbolo dessa unidade, como o mandatário de Deus na terra, para levar a cabo a missão civilizadora da raça lusa. No dizer de Borges de Macedo, "o espírito nacional acrescentava um poderoso valor vivencial à defesa do rei, representante da comunidade, constituída com recursos próprios e muito antiga. Esses dois factos (a nação e a sua antiguidade) aumentavam também a responsabilidade do rei na interpretação das necessidades do momento" ${ }^{\text {"4 }}$.

Mas, apesar destes valores, pesavam muito no Portugal dos Descobrimentos as limitações impostas pela problemática da sua política interna e externa, objecto ainda de muita indefinição.

A complexidade da máquina administrativa do Estado, causada pela expansão em África e no Oriente, vai fazer ascender aos altos cargos civis e militares um elevado número de homens especializados, provenientes em grande parte da burguesia endinheirada e cultivada. A nobreza acorre à corte para poder realizar as suas aspirações de classe privilegiada. Os membros do clero enxameiam o paço como con-

Vide Cabral Moncada, Filosofia do direito e do estado. Vol. I, Coimbra, 1947, p. 90.

Vide, e. g., Luís Reis Torgal, Ideologia política e teoria do estado na Restauração. Vol. I. Coimbra, 1981, p. 63 e sqq.

Sobre o significado do ideal heróico nacional, daquela mentalidade colectiva de que nasceu a epopeia, vide os estudos de Fidelino de Figueiredo, A épica portuguesa no século XVI: subsídios documentares para uma theoria geral da epopêa. São Paulo, 1950.

A própria noção de pátria adquire no Renascimento um sentido novo. Sobre o patriotismo como noção viva no século XVI, vide J. Delumeau, La civilisation de la Renaissance. Paris, 1967, p. 46-57; J. A. Maravall, Estado moderno y mentalidad social ( siglos XV a XVII), 2 vols., Madrid, 1972: vol. II, cap. IV: "El desarollo de un nuevo sentimiento de comunidad política. Formaciones políticas protonacionales", p. 457-525.

J. Borges de Macedo, "História e doutrina do poder n'Os Lusíadas, Sep. Garcia da Horta. Número especial comemorativo do IV centenário da publicação de Os Lusíadas. Lisboa, 1972, p. 351. 
fessores, pregadores, capelães, aios e preceptores de príncipes. A nobreza rural, no entanto, continua a lutar com sérias dificuldades e sente diminuídas as suas prerrogativas. Os lavradores e os mesteirais vivem em situação desfavorecida, num país onde a agricultura é desprezada e não há fontes de produção, a não ser o comércio dos produtos orientais que se esvaem na troca de bens de primeira necessidade.

É esta situação da política interna um dos factores da ambição, da inveja, da adulação e da hipocrisia da corte, que é retratada e criticada em profusão nas obras literárias do nosso século de ouro.

Neste contexto, que imagem nos é dada do príncipe perfeito do Renascimento?

Walter Ullman, ao comentar o carácter convencional de modelo de príncipe, apresentado através dos tempos por um eterno catálogo de virtudes, afirma que esta referência imutável precede o olhar do pintor, que traça o retrato do príncipe ideal e o condiciona ${ }^{42}$.

É, sem dúvida, verdade que desde Álvaro Pais, ou mesmo S. Martinho de Braga, a Diogo Lopes Rebelo, Frei António de Beja, D. Jerónimo Osório ou Bartolomeu Filipe, as quatro virtudes cardeais são enaltecidas, a par de muitas outras que lhe são indissociáveis, como no Carro triunfal de Maximiliano I de Dürer.

Se estes tratados repetem o "eterno" catálogo de virtudes, ele vai ser significativamente alargado e vai dar lugar a uma mais acentuada discussão dos problemas.

As reflexões de Álvaro Pais, no séc. XIV, alicerçadas sobretudo em passos da Sagrada Escritura e dos Padres da Igreja, embora dirigidas aos países da Península Ibérica, têm o "vinco dos escritos similares de São Tomás de Aquino e de Egídio Romano pensados para toda a cristandade" ${ }^{93}$. As citações de autores clássicos servem apenas para colorir as transcrições infindáveis de passos bíblicos ${ }^{44}$; dá-se relevo especial ao aspecto judicial e à arte da guerra, de que Vegécio, no Epitoma rei militaris, é cartilha.

Vide Walter Ullmann, Principles of government and politics in the Midle Ages. London, 1961, p. 300; Jacques Krynen, Idéal du prince et pouvoir royal en France à la fin du Moyen Âge (1380-1440). Étude de la littérature politique du temps. Paris, 1981, p. 54 e sqq.

Vide Joaquim de Carvalho, Estudos sobre a cultura portuguesa do século XVI, 2 vols., Coimbra, 1947-1948: I, p. 7.

Sobre a diferente utilização dos clássicos na literatura medieval e no Renascimento, vide Walter Ullmann, op. cit., p. 144-145 e 203, onde se exprime nestes termos: "Ma tutti questi autori antichi servivano per lo più d'aiuto a rivestire in materia decorosa un impianto intellettuale di carattere religioso". 
A concepção teocêntrica medieval do príncipe, um "ungido do senhor", vai cedendo terreno à visão antropocêntrica da vida, sem que a ortodoxia religiosa seja posta em causa. Esta laicização progressiva da cultura nacional está bem reflectida nos tratados portugueses do Renascimento, apesar do carácter convencional de que se reveste o modelo do príncipe.

Diogo Lopes Rebelo, no seu tratado De republica gubernanda per regem, dedicado a D. Manuel, é um marco importante da evolução do pensamento político, no que se refere à sua defesa da transmissão directa do poder, que coloca o rei "mais próximo e junto de Deus" 45 , o que prenuncia a tendência europeia para a afirmação do poder absoluto dos reis, definitivamente consagrado, entre nós, nas Ordenações Manuelinas (1505-1514) ${ }^{46}$. Medieval ainda na sua forma de argumentar, apesar do aproveitamento frequente das obras de Cícero e Aristóteles e da citação de outros autores clássicos, Diogo Lopes Rebelo manifesta já uma característica, que irá definir os tratados renascentistas: o pendor para a análise crítica de problemas reais de carácter social e político. O sentido da realidade é manifesto na discussão que apresenta de aspectos relevantes na época, tais como o da guerra justa e o da atitude a tomar pelo rei perante a presença dos judeus em Portugal ${ }^{47}$.

Lourenço de Cáceres é um dos primeiros autores que ilustram a literatura portuguesa com nítida influência clássica. A sua Doutrina ao Infante D. Luís ${ }^{48}$, escrita em 1525-1526, em Almeirim, onde a corte se instalara para fugir à peste, compõese de vinte capítulos, que não apresentam grande originalidade temática, em relação aos tratados tradicionais de educação de príncipes. As virtudes morais e intelectuais, os passatempos mais adequados a um príncipe e a moderação na sua prática são objecto de reflexão. O enroupamento clássico do discurso, dos exempla confere dignidade ao tema. A escolha da figura de Hércules e dos seus trabalhos adquire uma

45 Cf. Diogo Lopes Rebelo, Do governo da república pelo rei (De republica gubernanda per regem), reprodução fac-similada da edição de 1496 . Introdução e notas de Artur Moreira de Sá, Lisboa, 1951, p. XXIV-XXV.

46 Ibidem. Vide ainda Marcello Caetano, História do Direito português. Lisboa, 1941, p. 271. Sobre a análise da teorização do absolutismo em Portugal, que poderemos considerar moderado, vide Martim de Albuquerque, $O$ poder político no Renascimento português, Lisboa, 1968, cap. IX, maxime, p. 284 e sqq.

47 Cf. edição citada, introdução de Moreira de Sá, p. XXXIX-XL.

48 Além dos códices existentes nas Bibliotecas Nacional de Lisboa, Pública de Évora e da Ajuda, conhecem-se duas edições no séc. XVIII, a que figura nas Provas cit., (tomo II, II parte, Num. 78, p. 83 e sqq e em Filozofia de Principes, tomo I, p. 1 e sqq. Integra também a Antologia (séc. XVI), vol. I, p. 29 e sqq. 
carga simbólica e ilustra o motivo da "resplandecente gloria, que por fama de excelentes obras se alcança". Os poetas Homero, Hesíodo, Virgílio encontram-se referidos a par de Isócrates e de Platão com o seu modelo de rei filósofo (cap. VII). A ideia de que na paz é mais difícil a virtude é desenvolvida no cap. III, para no cap. IV serem denunciadas as guerras entre reis cristãos e elogiado o monarca português D. João III, empenhado apenas na luta contra o infiel. Os cap. V-VIII manifestam a importância das letras no príncipe; os cap. IX-XI, a necessidade de se rodear de bons conselheiros e privados; os capítulos seguintes tratam da filosofia moral, das virtudes cardeais, onde há lugar para a liberalidade (cap. XV). Finalmente (cap. XVI-XX) ocupa-se das práticas desportivas e passatempos do príncipe.

Esta obra, pela sua leveza e pessoalidade no tratamento dos temas, em que a mensagem dos autores da Antiguidade absorve os valores da moral cristã, é bem representativa do salto qualitativo que o género conhece no séc. XVI, pelo que a consideramos o termo a quo dos tratados de educação de príncipes portugueses, de nítida influência humanística.

Preocupam-se os autores do Renascimento por apresentar o retrato ideal do príncipe, num estilo novo, aperfeiçoado pela leitura dos autores clássicos, gregos e latinos, ou dos autores cristãos e dos grandes vultos da Patrística, tão frequentemente editados ao longo do séc. XVI. Procuram exprimir os valores humanos, quer de ordem religiosa, moral, social, política ou intelectual, que traduzem uma nova visão do mundo e uma nova imagem do príncipe. E afirmam-no explicitamente.

Significativo, neste sentido, é o passo da Doutrina ao Infante D. Luís, onde Lourenço de Cáceres se declara seguidor dos autores da Antiguidade: "E pois a glória da invençam nam pode ser minha, nam o deve ser a culpa da reprehençam; que de Pithagoras se lee dar conselho a muitos Princepes de Itália: se Solon à Cresso de Lidia: e Socrates à Alcibíades: e Isocrates à Niocles: e Plutarco à Antiocho: e Platam escreve à Dionizio Siracuzano: e Seneca à Nero: e outros muitos Philosophos à Princepes de seu tempo..."49.

Frei António de Beja, na sua Breve doutrina e ensinança de príncipes, dividido em três partes, correspondentes às virtudes sabedoria, justiça e prudência, abre com longas transcrições do De hominis dignitate de Giovanni Pico della Mirandola ${ }^{50}$.

49 Bento Jozé de Sousa Farinha, Filozofia de principes, I, p. 3.

50 Vide José V. de Pina Martins "Frei António de Beja, discípulo de Pico della Mirandola", Revista da Faculdade de Letras da Universidade de Lisboa, III série n. 8 (1964), 91-142. Mário Tavares Dias, Introdução e notas à sua edição do tratado de Frei António de Beja, 
Apesar disso, apresenta um leque de citações muito variado, em que a Sagrada Escritura, os Padres da Igreja, sobretudo Santo Agostinho têm uma representação assinalável, o que levou já a considerá-lo como um exemplo muito raro da última fase a que teria chegado a concepção do príncipe cristão que "debe vivir y gobernar puestos los ojos en la eternidad"51.

No Renascimento, a argumentação funda-se em exemplos retirados da própria história, considerada como modelo e mestra da vida ${ }^{52}$ e não em deduções teóricas abstractas. Melhor enraizados na história e mais preocupados com as relações definidas por Aristóteles ou S. Tomás entre a finalidade do estado, o direito natural e os mecanismos essenciais da comunidade, os tratados renascentistas, diferentemente dos anteriores, apresentam-nos o príncipe no centro de um sistema e não como objecto reconhecido do poder.

Os temas versados pelos humanistas, tradicionais em grande parte, revivem à luz das experiências clássicas, o que lhes confere um espírito, um significado novos.

Surge a imagem do rei, cabeça que rege o corpo ${ }^{53}$, constantemente empregada nos tratados medievais, depois de S. Tomás ${ }^{54}$. No entanto, esta imagem servirá de apoio ao "rigoroso intelectualismo ético", que denuncia a influência do platonismo neste género literário ${ }^{55}$. Além disso, rival do conceito "corpo político, desenvolvese então o de "estado", com uma ordem de referência que inclui a administração

Breve doutrina e ensinança de príncipes. Reprodução fac-similada da edição de 1525 , Lisboa, 1965, p. 28, 103 e sqq.

51 Vide José Maria Castro Y Calvo, El arte de gobernar en las obras de Don Juan Manuel. Barcelona, 1945, p. 204; cf. a introdução de Mário Tavares Dias à sua edição da Breve doutrina e ensinança de príncipes cit., p. 36.

Vide Cícero, De Orat. 2.9.

53 Vide Ernest H. Kantorowicz, The king's two bodies. Princeton, 1957, p. 270-271.

S. Tomás, Sum. Theol., I a, qu. 60, a.5; qu. 61, a.3; qu. 81, a 3 ad 2 - qu. 108. 4 - I a II ae, qu. 81, a.1 - I a, qu.81, a 3 ad 2. Vide Bernard Roland - Gosselin, Doctrine politique de Saint Thomas d'Aquin. Paris, 1928, p. 94 e n.4. Sobre esta inspiração medieval presente nas representações iconográficas renascentistas, vide Lawrence M. Bryant, The King and the city in the Parisian royal entry ceremony: politics, ritual, and art in the Renaissance, Genève, 1986, p. 137.

55 Vide, a este propósito, Margherita Isnardi Parente, L'educazione del principe cristiano di Erasmo da Roterdam. Trad. intr. e note, Napoli, 1977, p. 20; e ainda P. Archambault, "The analogy of the body in Renaissance political literature", Bibliothèque d'Humanisme et Renaissance, 29 (1967) 21-53. 
pública, a constituição e a estrutura do poder ${ }^{56}$.

A defesa do poder monárquico, a dicotomia estabelecida entre bom rei e tirano, a necessidade de afastar o rei de parasitas e aduladores, o enaltecimento da virtude do príncipe, presentes nos tratados medievais, figuram também nos tratados humanistas, temperados de muitos elementos novos, desconhecidos da Idade Média. Esta diversidade no tratamento dos temas provém da maior variedade de fontes e da evolução operada no pensamento político ao longo do séc. XVI, nomeadamente na teoria da soberania, com a afirmação do absolutismo e de uma nova estrutura do estado, dai decorrente ${ }^{57}$.

As próprias funções do rei sofreram alteração. Dirá Lester K. Born: "With the exception of some attention devoted to education, and some suggestions of economic development, the prince's functions are mainly divided between the military and the judicial" ". A estas funções de carácter militar e judicial, primordiais no ministério régio medieval, acrescentam-se ainda, entre outras, as de carácter legislativo. O poder legislativo do rei aumenta de forma significativa à medida que as estruturas centralizadoras e administrativas da monarquia se consolidam. A realização concreta do princípio do soberano depositário de todos os poderes e fontes do direito, decorrente de profunda romanização jurídica da vida privada e pública europeia, leva mesmo à necessidade da recolha das leis para as tornar acessíveis aos súbditos.

Em Portugal, além das Ordenações régias, há todo um conjunto de leis decorrentes da função legislativa dos soberanos, que adquirem valor de direito positivo e são recolhidas, a pedido do rei, em colectâneas ou compilações ${ }^{59}$.

$\mathrm{Na}$ verdade, a valorização intelectual do governante e o seu poder legislativo, que a tratadística medieval descurava, prendem-se ambos com a consolidação do conceito de soberania no séc. XVI, apoiado por uma corrente de nacionalismo jurídico, que exalta a personalidade régia e suas funções.

Vide Peter Burke, The Italian Renaissance culture and society in Italy, Cambridge, ${ }^{3}$ 1987, III parte "The wider society", p. 188-189.

57 Marguerita Isnardi Parente, L'educazione cit., p. 23.

58 "The perfect prince: a study in thirteenth and fourteenth century ideals", Speculum 3 (1928) 470-504: citação, p. 504.

59 Vide, e. g., as Leis extravagantes collegidas e relatadas pelo licenciado Duarte Nunes de Lião, per mandado do muito alto e muito poderoso rei Dom Sebastião nosso Senhor. Coimbra, na Real Imprensa da Universidade, 1796. Sobre o que se passa nos vários estados italianos, em Espanha, França, vide o artigo de V. Piano-Montani, "Problèmes des États de la Renaissance", Pouvoir et institutions en Europe au XVIème Siècle (XXVII Colloque International de Tours), Paris, 1987, p. 8-11. 
$\mathrm{O}$ alargamento das funções régias - com nítidos reflexos no retrato ideal do príncipe -, favoreceu a formação de várias dependências estatais, sobretudo num país como o nosso, que se estendia até aos confins da Índia ${ }^{60}$. Surgem alusões à grande máquina do estado, comparada a um relógio e suas engrenagens ${ }^{61}$ e à incapacidade de o rei abarcar sozinho, sem a ajuda de personalidades bem preparadas e virtuosas, a sua direç̧ão exclusiva, a ingente tarefa da governação.

A realidade portuguesa da época, a menoridade de um rei, voluntarioso e indómito no seu querer, levaram à proliferação de uma literatura pedagógico-política, a uma literatura - por assim dizer — de intervenção, que procurava advertir o rei das suas funções, da responsabilidade do seu ofício, do perigo que representava a sua incúria ou o favoritismo que presidia à escolha dos homens de estado. Primoroso neste sentido é o mais completo tratado de pedagogia política, referência privilegiada da definição do retrato do príncipe no Renascimento português, o De regis institutione et disciplina de Jerónimo Osório. No livro VI, pronuncia-se desta forma ${ }^{62}$ : Rex igitur, qui munere suo cum laude perfungi cupit, multos Reges muneris socios habeat necesse est: aliter enim frustra studium, \& industriam, atque adeo uitam in Regno tuendo consumet. Reges autem appello, qui uirtute Regia ornati sunt, quamuis Regnum minime possideant...., “...Portanto o rei que deseja com louvor desempenhar o seu cargo deve ter vários reis, companheiros de ofício, pois de outra forma perderá em vão o seu esforço, a sua dedicação e até a própria vida na governação do reino. Reis é o que eu chamo àqueles que são dotados de virtude régia, ainda que não possuam qualquer reino...".

Ao considerar, na dedicatória, o tema da obra, em termos gerais, afirma Osório tratar nela da educação, do ofício de rei e sua dignidade (I. 259.30-31). O poder entendido como um ofício, que a tradição lhe oferecia, e sua definição são aspectos

60

D. Jerónimo Osório, no início do livro IV do seu De regis institutione et disciplina (Op. Om. I, 356, 10), ao aludir à dignidade do nome de rei e à definição do seu munus exprime a complexidade do seu desempenho, na pátria portuguesa, tão ampla e diversificada.

61 Vide a este propósito J. A. Maravall, Estado moderno, I, cap. I "El estado como artifício humano", p. 56 e sqq.; Augustín Redondo, Antonio de Guevara (1480?-1545) et l'Espagne de son temps. (De la carrière officielle aux oeuvres politico-morales), Genève, 1976, p. 529530. A Frei António Guevara, autor de Relox de príncipes se deve a vulgarização do emprego do termo 'relógio' com uma coloração moral incontestável. Com este sentido se encontra, por exemplo, em Frei Heitor Pinto, Diálogo de Justiça, ed. cit., p. 169. No entanto, na doutrinação de D. Jerónimo Osório esta metáfora adquire um acentuado valor político-mecânico. Cf. os passos do De regis institutione et disciplina, do De nobilitate civili e do De Justitia, citados por J. A. Maravall, Estado moderno cit., p. 38 n. 93. 
salientes da elaboração política do autor. Diríamos mesmo que ao ofício de rei, uicarius Dei e minister populi, se resume toda a essência da obra.

A ideia de Deus, arquétipo político, tem já as suas raízes na exaltação do ideal monárquico de cariz estóico, presente em autores como Platão ( $R$. 473d), Cícero (Rep. 1.56), Musónio Rufo (fr. 8), colhido pela ideologia imperial e presente em autores como Plínio-o-Velho. Santo Ambrósio, apoiado em S. Paulo, vai ao encontro desta filosofia. Toda a teorização do príncipe cristão desde Santo Ambrósio, Santo Agostinho e sobretudo S. Tomás, e seus seguidores, se vincula a esta ideiamestra do pensamento político antigo e medieval. A escola de Salamanca, com Francisco de Vitória, vai ser no séc. XVI a principal difusora da doutrinação tomista, também neste particular.

Osório considera o poder de origem divina, e o rei, ministro e vigário de Deus, cuja sabedoria deve imitar (I. 356.51-357.24).

Esta filiação em S. Tomás denuncia-se sobretudo na concepção da origem divina do poder por mediação do povo: a fidelidade ao juramento, obligata fides (I. 356.48-357.3), feito perante o povo, que o confirma como rei (I. 357.51-57; 357.61358.8), o rigor da justiça correctiva e distributiva (I. 357.24-358.42), a defesa do direito divino, do direito natural, do direito positivo (I. 358.42-46), a obediência e respeito do rei às leis (I. 410.58-411.29), e a primazia do bem colectivo sobre o particular (I. 358.42 e sqq.). Era o modelo da monarquia de cariz providencial e teológico - que surgira em Roma no séc. I, com a crise da república - a que o pitagorismo poderá ter fornecido um dos quadros ideológicos de referência ${ }^{63}$. A assimilação destes valores da filosofia grega nas concepções políticas dos autores cristãos encontra-se desde a Patrística.

Um pormenor confere actualidade a esta teorização, na obra de Osório: a regis maiestas é inerente ao ofício de rei, considerado divino pelo alcance de deveres e obrigações que abrange, pelas virtudes que requer. Dirá Osório ${ }^{64}$ : "É que a majestade, a grandeza do rei é demasiado excelsa para que alguém possa aspirar a igualarse ou sequer parecer-se com ele".

62

63

64

H. Osorii Op. omnia, I, 425.62 - 426.7.

Vide, a este propósito, A. Michel, La philosophie politique à Rome d'Auguste à MarcAurèle cit., p. 24 e sqq.

H. Osorii Op. omnia, I, 440.3-7: Regis autem Maiestas, et amplitudo sublimior est, quam ut quisdam ad illius aequalitatem, et similitudinem adspirare queat. 
Por este motivo deve o rei manifestar o maior zelo pela religião e sua prática (I. 456.21-24). No entanto, com o pensamento na doutrina de Maquiavel, Osório lembra $^{65}$ : "os que pensam que a dignidade fica diminuída com a prática da religião cristã e tacitamente sugerem que a piedade cristã contém algo de indecoroso e de indignidade à mistura".

É este o início de um longo ataque à doutrina do Florentino, que se manifesta mesmo a nível dos exempla: embora Maquiavel pretendesse com o seu plano político restaurar a grandeza da Roma antiga, não segue as pisadas dos antigos Romanos, no que respeita ao zelo e superstição religiosa. Os exempla que Osório apresenta (I. 457.13-36) são disso significativos.

Logo no início deste tratado (I. 257.38-47) surge, por oposição à crueldade e intemperantia do tirano, a apresentação do ofício de rei encarado não apenas numa perspectiva de acção governativa, mas sobretudo numa dimensão ética. Mais adiante (I. 258.10 e sqq.), dirigindo-se ao rei D. Sebastião, como o mostra o emprego do pronome pessoal da segunda pessoa do singular, encarece o mérito individual, que leva ao bom exercício do governo. Apresenta, em I. 261.60-262.6, pela primeira vez, a definição de rei perpetuus reipublicae rector atque moderator e, em íntima ligação com este conceito, o ofício de rei.

De novo retomará esta asserção em termos semelhantes ${ }^{66}$ : "É que o rei, como já antes referimos, é acima de todos, o único e perpétuo chefe e protector do povo inteiro".

A carga semânica da expressão rector atque moderator que encerra em termos ciceronianos $^{67}$ a noção de governante perfeito, vai muito além da sua tradução em qualquer língua. É baseado no sentido pregnante destas duas palavras que Osório vai definir o ofício de rei, o seu papel junto da comunidade, que dirige ${ }^{68}$ : "Se não é

H. Osorii Op. omnia, I, 456.57-61: Qui enim Christianae religionis studio, dignitatem imminui censent; tacite indicant, esse Christianae pietati aliquid dedecoris, et indignitatis admixtum.

H. Osorii Op. omnia, I, 355.47-50: Est igitur, ut ante diximus, Rex excellens et unicus, atque perpetuus populi universi rector, atque moderator.

67 Esta noção de governante perfeito, o rector ou moderatur, surge no livro V do De republica de Cícero.

68 H. Osorii Op. omnia, I, 356.2-11: Si enim non mediocris uirtutis est, animum regere, cupiditati modum statuere, iracundiam cohibere, inconsideratos animorum motus ratione compescere; quantum tandem erit, non unum tantum populum, sed multas ciuitates, et nationes, plurimum inter se moribus, institutis, atque natura dissidentes, sapientia regere, disciplina moderari, iure deuincire, uirtute defendere? 
pequena virtude reger o espírito, impor moderação aos desejos, dominar a irascibilidade, controlar pela razão os movimentos desordenados da alma, quanto o não será, enfim, governar com sabedoria, disciplinar pela instrução, conter pelo direito e defender pela virtude não um só povo, mas muitas cidades e nações, muito diferentes entre si nos costumes, nas leis, nas instituições e maneira de viver?"

O sentido moral, que preside à noção política do nome de rei, a que o bom desempenho do seu ofício confere significado e dignidade, é adequado, neste contexto, ao governante português, senhor de um império. A condução moral do povo, implícita em todos os passos do tratado, em que se alude ao ofício de rei, tem mesmo a primazia sobre a actuação política ${ }^{69}$ : "O ofício de rei não consiste só em atender ao bem-estar e salvação da pátria, ou em repelir as forças inimigas dos confins do reino com grandes e belicosos recontros, mas muito mais ainda em cortar com paixões libidinosas, refrear a petulância, arrancar as raízes da iniquidade e da injúria, embelezar o reino inteiro com os ornamentos da honestidade e torná-lo forte com o sustentáculo de todas as virtudes?"

Para fundamentar as exigências morais que o cargo de rei requer, apresenta Osório uma concepção muito elevada do homem e da sua natureza.

Todos os ornamentos e defesas, tais como as letras, o apoio de homens avisados, a religião, os dotes de natureza, do espírito, da instrução e da educação devem ser orientados para o bom desempenho do ofício de rei, dada a importância de que este se reveste (I. 469.1-13).

$\mathrm{O}$ ofício de rei exige sabedoria. Só o rei-filósofo pode dar cumprimento à tarefa ingente, ao munus diuinus que lhe é imposto. É o modelo de Platão, que Osório ressuscita (I. 557.9-13) para o encarnar em D. Sebastião.

Este alto conceito do chefe supremo da comunidade política traduz-se na dignidade do seu ofício. Ao rei cabe a cura morum, uma verdadeira missão ética Principis autem officium est, ad uirtutem omnes incendere (I. 436.51-53) - e o cumprimento de um vasto programa concreto.

Às múltiplas facetas, que englobam o regis officium, vão merecer tratamento a partir da definição de funções do rei homérico: sacerdote, orador, juiz, chefe militar.

H. Osorii Op. omnia, I, 262.23-30: Regis igitur officium est, nom solum commodis patriae, atque saluti consulere, et hostium impetum a finibus Regni, magna belli contentione, reprimere; sed multo etiam magis resecare libidines, coercere petulantiam, iniquitatis, et iniuriae fibras euellere, uniuersamque Rempublicam honestatis ornamentis officere, uirtutumque omnium praesidiis firmare. 
As funções do rei homérico merecem um tratamento adequado à realidade concreta nacional, que se presta a considerações de verdadeira intervenção: a defesa da comunicação oral e fácil acesso dos súbditos ao rei, que deve conhecê-los pelo nome (I. 480.58-481.15) - tal como D. Aleixo de Meneses, aio de D. Sebastião, recomendava ao seu discípulo —, dificultada por cortesãos e aduladores ${ }^{70}$; a participação do rei nos julgamentos - conhecido fícou o zelo da justiça de D. João III $^{71}$ - a que deve assistir e em que, nas causas mais difíceis, se for caso disso, interpor a sua autoridade (I. 479.52-480.21); a morigeração e disciplina dos soldados (I. 495.36-40), o reconhecimento do mérito devido aos soldados, defensores e guardiões da pátria (I. 480.42-58).

O ofício de rei abarca todos os domínios da actividade humana, que estão sujeitos à sua superintendência, virtude, moderação, exemplo (I. 478.8-30). A imagem do rei-arquitecto, colhida na tradição clássica ${ }^{72}$, que Leon Battista Alberti faz reviver de forma expressiva, serve a Osório para exprimir a sua concepção de iudex ingenii, que superintende à estrutura e organização da cidade (I. 481.44-50).

Assim se compreende que, em face da ingente tarefa da governação, seja dada maior importância ao papel dos cortesãos, dos conselheiros do rei, que se pretende sejam prudentes no conselho, experimentados na arte de governar e na condução da guerra ${ }^{73}$.

D. Aleixo de Meneses na sua Fala sobre a educaçam do senhor Rey Dom Sebastiam (Filosofia de Príncipes, I, cit., p. 78) considera uma das causas da perturbação de paz e estabilidade do reino "apartarem os principes da affabilidade e communicaçam dos seus vassallos, em particular dos nobres, persuadindolhes, que a verdadeira grandeza consiste em dar pouca parte de si ao povo, e acrescentar com severidade o respeito, e veneraçam proprio da Magestade Real, que nunca he bem respeitada, sem ser em alguma maneira temida: attendendo nisto a converter em si a graça, e favor popular, que tiram ao Príncipe, enquanto (como Internuncios) dam repostas, e dispensam mercês, que os Reys houveram de fazer por si mesmos".

71 Frei Amador Arrais, Diálogos, edição com introdução e revisão de M. Lopes de Almeida, Porto, 1974, "Diálogo V - Das condições do bom príncipe", p. 338, apresenta D. João III como modelo de governante, no que se refere ao zelo da justiça, segundo os nossos costumes e instituições.

Vide a este propósito Platão, Plt. 259c-e, Aristóteles, Eth. Eud. 1217 a 6; Eth. Nic., 1141b24; Pol. 1325 b23.

73 A competência dos conselheiros como critério que preside à sua escolha é defendida já nos tratados medievais e com grande insistência nos renascentistas. Vide Jacques Krynen, Idéal du prince et pouvoir royal en France à la fin du Moyen Âge (1380-1440). Étude de la littérature politique du temps, Paris, 1981, p. 147; CL. Bontems, Le prince dans la France des XVIe et XVIIe siècles, Paris, 1965, p. 59; Martim de Albuquerque, A 
Eram estes os cortesãos ideais dos tratados do Renascimento português ou do poema épico de Camões (Lus. VIII, 54-55; X, 149, 152-153 e passim), bem diversos quer do modelo estético de Castiglione, quer do tipo de aventureiro traçado por Maquiavel. Jorge de Sena, que considera o final do canto IX (Lus., IX, 92-95) "um regimento para ministros, para conselheiros, para governadores ultramarinos, para chefes de exército e de armada" ${ }^{, 74}$, refere-se nestes termos aos agentes da administração pública da nação: "Capitães de frota, comandantes de fortaleza, vice-reis da Índia, todos eram no mundo de Camões, ainda que prepostos do rei, pequenos príncipes locais, autónomos e responsáveis, a uma infinita distância do Poder Central, que levava dois anos a destituí-los. E tinham, pois, prerrogativas que exigiriam deles uma consciência muito maior dos limites e das consequências da iniciativa popular"75.

A realidade portuguesa, traduzida numa política missional ${ }^{76}$, a da expansão oceânica, propiciou uma verdadeira "civilização luso-tropical"" . A própria constituição de um sistema organizado de relações comerciais entre a metrópole e as várias possessões, que dela distavam milhares de léguas, não excluía os interesses regionais destes territórios, tão diversos do centro do Império, geridos por governadores, administradores do $\mathrm{rei}^{78}$.

Surge então uma literatura paralela aos tratados de educação de príncipes, que se dirige especificamente a formar conselheiros e ministros e que se refere aos costumes de todo um grupo social que de alguma maneira participa no poder. Estas obras ligam-se a toda uma literatura cortesã que vai desde $I l$ cortegiano de Baldassare Castiglione e Il Galateo de Giovanni della Casa ao tratado de La civile conversazione de Guazzo ${ }^{79}$. Destas últimas, os tratados portugueses conservam o espírito sobretudo no que diz respeito à nobilitas morum, apesar de a matéria ser adaptada à realidade portuguesa do séc. XVI.

sombra de Maquiavel e a ética tradicional portuguesa (ensaio de história das ideias políticas), Lisboa, 1974, p. 52.

Vide Jorge de Sena, A estrutura, p. 160.

75 Ibidem, p. 162-163.

Vide Martim de Albuquerque, A sombra de Maquiavel, p. 51.

Davide Bigalli, Immagini del principi. Ricerche su politica e umanesimo nel Portogallo e nella Spagna del Cinquecento. Milano, 1985, p. 27.

78 Cf. Vitorino Magalhães Godinho, L'économie de l'empire portugais au XV $V^{\grave{m} e}$ et XVİ̀e siècles. Paris, 1969, p. 833; Davide Bigalli, ibidem.

79 A este propósito, vide E. Garin, L'éducation de l'homme moderne (1400-1600), trad. fr. (ed. it. Bari, 1966), Paris, 1968, p. 139 e sqq. 
A própria realidade factual vai oferecer uma maior autenticidade e veracidade aos temas tradicionais e servir de motivo de reflexão. Assim, por exemplo, o tema da guerra justa vai ser tratado, entre nós, ainda em termos medievais (guerra justa, para além da que se ocupa da defesa, é a que se empreende contra os Turcos, que ameaçam a Europa, e a que combate os infiéis) e não nos termos modernos dos teorizadores espanhóis. Contudo, a tratadística da época confere uma nova dimensão a este tema. Referimo-nos à critica constante dos príncipes cristãos, que se combatem por ambição humana, contrapostos ao pacífico D. João III. A exaltação da paz portuguesa tornou-se um topos na nossa literatura quinhentista, assimilada, no contexto epocal da expansão ultramarina e da constituição de um império oceânico, à pax Augusta romana ${ }^{80}$.

Exemplificativa ainda do interesse pelo real como base de doutrinação é a caracterização do tirano, feita já pelos tratadistas medievais e pelos autores clássicos. Nesta caracterização do tirano se incluem sempre os cortesãos, aduladores do seu procedimento, zelosos do seu bem privado e detractores do alheio, que prejudicam o interesse colectivo com o seu conselho e a sua ociosidade luxuosa. Os autores renascentistas, reagindo à situação das cortes do século de ouro europeu, censuram vícios reais, que é necessário corrigir. Nos tratados portugueses desta época quase sempre subsiste implicitamente, pelo menos, uma crítica senão aos abusos das instituições ou do próprio rei, pelo menos à organização de uma sociedade civil - que não esconde o favoritismo - ao ambiente cortesão, aos conselheiros e íntimos do rei, como transparece claramente das obras de autores como Diogo de Teive e sobretudo de D. Jerónimo Osório.

O humanista bracarense, depois de ter reflectido nestes termos:

Porém não ha nenhum que negar ouse,

Que assi como esta grande, e Real Corte

Está de muitos males rodeada,

Assi tambem mil vicios em si cria ${ }^{81}$,

dirige a Francisco Sá de Meneses estas palavras:

Tão perigosa a todos tão damnosa

E muito mais aos Reis, lisonjaria

Vide Américo da Costa Ramalho, "A nossa Júlia modesta", Estudos sobre a época do Renascimento. Coimbra, 1969, p. 151.

81 Diogo de Teive, Institutio Sebastiani Primi, em tradução, in Epodos Que Contém Sentenças Uteis A Todos Os Homens, Às quaes se acrescentão Regras para a boa educação de hum principe. Trad. no vulgar em verso solto por Francisco de Andrade (conforme à ed. de Lisboa, 1565). Lisboa, Na Of. Patr. de Francisco Luiz Ameno, MDCCLXXXVI, p. 109. 
E se tu grão força, e grão virtude, (Que são obras do teu heroico sprito) Dessa Casa Real tal monstro lanças, Generoso Francisco, grandes ódios Alcançarás da hi, eu to confesso ${ }^{82}$.

D. Jerónimo Osório ocupa quase um livro inteiro, o livro II, e grande parte dos livros III e VI do De regis institutione et disciplina, a insurgir-se contra a adulação e os aduladores.

Idêntica atitude ressalta nitidamente nas obras da época, de que são um bom exemplo a Carta de Sá de Miranda a D. João III e o poema épico Os Lusíadas, onde a doutrinação política se acompanha de um verdadeiro "sentido da realidade" ${ }^{, 83}$. As lições de moral política, de virtude pública e privada, transmitịdas sobretudo nos finais dos cantos (Lus. V, VI, VII, VIII, X) são introduzidas pelo poeta "para doutrinar, para criticar, para persuadir" ${ }^{84}$. A própria mitologia é utilizada com a mesma intenção, como é o caso do mito de Actéon (Lus., IX, 26-28), interpretado como uma alegoria contra os aduladores, que devoram o próprio dono, tal como fizeram os cães de Actéon, ou como insinuação denunciadora dos excessos venatórios e misoginia de D. Sebastião ${ }^{85}$. Aliás, como afirma Jorge Borges de Macedo, a primeira parte do poema contém uma teoria própria sobre a história de Portugal, até D. Manuel, e seus heróis, "símbolos, expressões de uma orientação superior que se executa com glória e esforço"; a segunda parte, iniciada por "um verdadeiro panfleto", contém "as mais severas críticas ao poder e à necessidade de cumprir a missão de cantar, sem traição, os verdadeiros heróis da Índia" ${ }^{\nexists 6}$.

A Aulegrafia de Jorge Ferreira de Vasconcelos, verdadeiro speculum consuetudinis, a Castro de António Ferreira, "que aspira — no dizer de Eugenio Asensio — a ser

Ibidem, p. 117. Cf. ainda p. 130-131.

83 Jorge Borges de Macedo, "História e doutrina" cit., p.354-355; Maria Helena Ureña Prieto, "O 'ofício de rei"” cit., p. 769-772.

84 Vide José Figueira Valverde, “' 'Os Lusíadas' em si mesmos, como monumento”, in Reunião Internacional de Camonistas. Comunicação de base. Lisboa, Comissão executiva do IV centenário da publicação de "Os Lusíadas", 1972, p. 15; Afrânio Peixoto, Ensaios camonianos. Coimbra, Imprensa da Universidade, 1932, p. 34; Martim de Albuquerque, A sombra de Maquiavel p. 62.

85 Cf. Américo da Costa Ramalho, Estudos camonianos. Lisboa, ${ }^{2} 1982$, cap. IV “O mito de Actéon em Camões", p. 45-68. 
um espelho de príncipes" "87; a Ioannes Princeps tragoedia de Diogo de Teive, que põe em cena a figura do próprio rei e o drama nacional, vivido por ocasião da morte do príncipe João, único herdeiro do reino, antes do nascimento de seu filho, D. Sebastião ${ }^{88}$; as obras dramáticas do $\mathrm{P}^{\mathrm{e}}$. Luís da Cruz, Josephus, Sedecias e Vitae humanae, que retratam e denunciam a situação político-social do reinado de D. Sebastião ${ }^{89}$, documentam a realidade portuguesa, ilustram a importância que a filosofia política, com o seu retrato ideal de príncipe, assume no teatro do Renascimento.

A importância da realidade política na problemática do teatro do Renascimento, denunciada nas várias realizações dramáticas da época está documentada na própria teorização literária. O italiano Giraldi Cinzio, em 1554, refere-se à necessidade de apresentar a actualidade na cena teatral "per servire agli spettatori, e farle riuscire più grate in scena, e conformarmi più con 1 ' uso dei nostri tempi" ${ }^{\prime 90}$. $\mathrm{O}$ princípio da função educativa da obra dramática e sobretudo da tragédia ${ }^{91}$ - que põe em cena personagens de condição elevada, o próprio rei, seus familiares, a sua corte encontra desta forma uma viva expressão.

Assim se compreende o papel que os poetas trágicos ocupam nos tratados de educação de príncipes do Renascimento. Significativo é o exemplo de D. Jerónimo Osório que não só cita estes autores como ainda reflecte sobre a condição da realeza, apoiando-se na tragédia, reflexo da realidade histórica ${ }^{92}$.

87 Eugenio Asensio, “Inés de Castro. De la crónica al mito", in Estudios portugueses. Paris, 1974, p. 53. Cf. também, a este propósito, Martim De Albuquerque, A sombra de Maquiavel, p. 64-65.

88 Vide Nair de Nazaré Castro Soares, A tragédia do príncipe João de Diogo de Teive, Lisboa, ${ }^{2} 1999$.

${ }^{89}$ Vide Claude-Henri Fréches, Le théâtre neo-latin au Portugal. Paris-Lisbonne, 1964, chap. X, p. 281-330; p. 361-401.

90 Discorso ovvero lettera di Giovambattista Giraldi Cintio, intorno al comporre delle commedie e delle tragedie a Giulio Ponzio Ponzoni, in Scritti estetici. Milano, 1864, parte seconda, p. 34.

91 Sobre a função educativa da tragédia, vide Robortello, no seu comentário à Poética de Aristóteles, ao tratar da tragoedia ethica, a tragédia de caracteres (Francisci Robortelli Vtinensis in librum Aristotelis de arte poetica explicationes. Florentiae, in officina Laurentii Torrentini Ducalis Typographi, 1548, p. 210-211). Vide sobre este assunto o nosso artigo "A Castro à luz das suas fontes", Humanitas 35-36 (1983-1984), p. 305 n. 78; p. 314-315 e 345-347.

92 Vide, e. g., De regis institutione et disciplina, lib. I (Op. Omnia, I. 253.20; I. 254. 30) e lib. VI (Op. Omnia. I, 441. 30-40). 
Um outro pormenor da presença do real na argumentação dos nossos tratados, embora tópico humanista, é a reflexão sobre o conceito de verdadeira nobreza, que reside nas virtudes morais e humanas, dada a valorização da vida palaciana, e a mania da nobreza dos portugueses do séc. XVI, de que a Aulegrafia e a correspondência de Clenardo nos dão um quadro pitoresco ${ }^{93}$.

A aspiração social de viver na corte, ou em contacto com ela, ou à maneira da corte, favorece a migração urbana ou a aventura marítima, como fonte de riqueza, e explica o abandono dos campos ${ }^{94}$ e a penúria de bens de primeira necessidade. Esta situação leva os nossos tratadistas, como Jerónimo Osório, a reflectirem sobre a importância que o monarca deve dar ao desenvolvimento da agricultura. As Geórgicas de Virgílio e os vários tratados De agricultura, que os prelos europeus frequentemente reeditam, inspiram-lhes o discurso, a realidade nacional a veemência do tom.

A imagem do governante é decorrente do seu ofício, da finalidade do estado.

O nome de rei é um conceito de grande significado. No início do De nobilitate ciuili afirma D. Jerónimo Osório que "nada existe mais sublime na humanidade do que o nome de rei".

A definição tradicional da realeza com base em princípios éticos e não jurídicos, que se exprime entre nós já em Álvaro Pais, prende-se com a noção de uera nobilitas, de grande significado no Renascimento. A cada passo surge no De regis institutione a imagem do verdadeiro rei, o que o é por mérito (qui uere rex est), em oposição àquele que falsamente se atribui o nome (qui falso regis nouem usurpat), isto é, que usa o seu nome sem o merecer ${ }^{96}$.

Dirá Osório, no livro VI ${ }^{97}$ : "Eu chamo reis aqueles que possuem o ornamento da virtude régia, muito embora não possuam reino algum". Noutro passo especifica ${ }^{98}$ :

M. Gonçalves Cerejeira, Clenardo (com a tradução das suas cartas). Coimbra, 1926: "Carta a Látomo", p. 271-273. Cf. também Miscelânea de Garcia de Resende.

Vide e. g. M. Gonçalves Cerejeira, Clenardo, p. 271. Luís de Matos, Les portugais en France au XVI siècle. Etudes et documents. Coimbra, Acta Vniversitatis Conimbrigensis, 1952, p. 89, que cita o testemunho de J. Nicot. Vide a correspondência deste embaixador francês em E. Falgairolle, Jean Nicot, ambassadeur de France au

H. Osorii Op. omnia I, 2.1: nihil in rebus humanis est Regio nomine sublimius.

Vide H. Osorii Op. omnia I, 257.59-61.

Vide H. Osorii Op. omnia I, 426.5-7: Reges autem appello, qui uirtute Regia ornati sunt, quamuis Regnum minime possideant.

Vide H. Osorii Op. omnia I, 256.3-6: Rex enim ille demum habendus est, qui longe, multumque reliquis hominibus honestatis opibus, et ornamentis antecellit. 
"Enfim, rei deve ser considerado aquele que de longe e em muito sobressai entre todos, em dons e ornamentos de virtude".

Muitas vezes a imagem do bom rei surge em contraste com a do tirano, topos que remonta à tradição medieval ${ }^{99}$ e que desde o Hieron de Xenofonte e os tratados de um Bartolo de Sassoferrato ou de um Coluecio Salutati não mais deixou, até finais do séc. XVI, de se pôr à reflexão ético-política. As tragédias de Séneca, ou ao modo senequiano, contribuíram também significativamente para actualizar este tema $^{100}$. Logo no exórdio, antes de dar início ao diálogo (I. 257.21-38), introduz Osório este quadro do bom rei e do tirano que desenha com traços bem vincados, de modo a ficarem impressos no espírito do rei. Além dos elementos tradicionais que caracterizam os vícios do tirano, existe neste passo mais do que uma velada insinuação à doutrina de Maquiavel em Il principe: o menosprezo da religião e dos direitos humanos, a insistência no dolo, na fraude, na violência, na falsa imagem da honra e dignidade, na crítica à uirtù.

O tom preventivo é também sublinhado em alguns passos que, para mais facilmente ficarem no ouvido, ganham um tom sentencioso e um ritmo tipicamente proverbial (I. 257.15-16): Rex enim temerarius, et insanus, non Rex, sed tyrannus...

Num passo anterior, apontara Osório a falta de obediência como causa primeira de insânia, nestes termos ${ }^{101}$ : "É que eles não vêem que a ciência da governação consiste não só em mandar como ainda em obedecer". A lição era de Aristóteles (Política, 1278 b 30-1279a 21), mas a mensagem, não há dúvida, era dirigida a D. Sebastião.

É nestes termos tradicionais que a imagem do governante no De regis institutione se ilumina, se decora.

A concepção religiosa do príncipe, que dominou a Idade Média e se firmou em certos aspectos na época seguinte - nomeadamente no que se refere à instituição no poder por direito divino, que remonta a S. Paulo (Rom. 13.1), à governação entendida como um ofício que, se confere a mais alta dignidade é o mais oneroso de todos, ou ainda à responsabilidade da acção e exemplo do príncipe, que o cristocentrismo erasmiano alimenta - cede lugar ao enaltecimento vivo da sua humanidade.

99 Muito embora este tema se encontre já na Antiguidade grega desde Homero e sobretudo nos autores da época helenística, são os tratadistas medievais que o vulgarizam em termos de dicotomia ético-política.

${ }^{100}$ Vide, e. g., o coro que termina o acto I da Ioannes Princeps tragoedia de Diogo de Teive, p. 155-161 da nossa edição.

${ }^{101}$ H. Osorii Op. omnia, I, 256.58-60: non enim uident, regnandi scientiam, non tantum in imperando, sed etiam in oboediendo consistere. 
Uma nova concepção de ideal de vida e de perfeição humana se delineia com os alvores do Renascimento.

Já Azurara, ao apresentar-nos, na Crónica dos feitos da Guiné, a figura do infante D. Henrique, como que decalcada de um espelho de príncipes, caracteriza-a com elementos do seu pré-humanismo, pondo em relevo os dotes intelectuais do infante, rodeado de sábios.

No entanto, a exaltação do governante em termos humanistas, surge da pena de Cataldo Parísio Sículo, a quem cabe o mérito de pela primeira vez, entre nós, ter definido um tipo de homem moderno, que se iria definitivamente impor no Renascimento ${ }^{102}$. Além disso, as suas composições têm ainda o interesse de se dirigirem ou ao monarca português ou a figuras da nobreza, verdadeiros príncipes.

Referimo-nos, por exemplo, ao panegírico poético de D. Pedro de Meneses, feito por Cataldo no Terceiro Livro das Visões, onde são enaltecidas as suas qualidades, os seus dotes espirituais e físicos. Curioso é o pormenor de o Conde, a quem a musa Calíope serviu de ama, ter por protótipo "o rei D. Manuel, modelo de todas as perfeições"103.

Também no seu poema De perfecto homine ${ }^{104}$, este humanista faz o retrato físico e moral de D. João II, elucidativo da identificação, no humanismo, do ideal de príncipe com o ideal do homem perfeito. Dirá Cataldo, no prólogo do poema: nihil sublimius homine perfecto eiusque sensibus in hoc saeculo inueniri potest, "nada de mais sublime se pode achar neste mundo mais sublime do que o homem perfeito e os seus sentimentos" ${ }^{\prime 105}$.

Gioacchino Paparelli, na obra que ocupa da essência humanística do Renascimento, cita Cataldo a par de Pico della Mirandola, entre outros, como intérprete dos ideais

${ }^{102}$ A importância de Cataldo Parísio Sículo como introdutor do humanismo em Portugal e como difusor dos ideais humanistas, na corte portuguesa de D. João II, foi posta em rele-' vo pelos numerosos e fundamentados trabalhos de Américo da Costa Ramalho (vide, $e$. g. "A introdução do humanismo em Portugal", Humanitas, 23-24 (1972), 435-452.

103 Vide Américo da Costa Ramalho, "A introdução do humanismo", cit., p. 451.

${ }^{104}$ Depois incluído nos Poemata, saídos a lume, conjuntamente com as Epistolae et orationes quaedam Cataldi Siculi (cf. exemplares na B.G.U.C. e B. M. Porto), encontra-se na Biblioteca Marciana de Veneza: cod. 235 (3960). nbr. XV. Cf. P.O. Kristeller, Iter Italicum, II, London-Leiden, 1967, p. 343.

105 Vide Ana Maria Osório Pereira de Melo, O homem perfeito de Cataldo Sículo. Dissertação de licenciatura, dactilografada, orientada por Américo da Costa Ramalho. Coimbra, 1969, p. 96-97. 


\section{expressos desde o De dignitate et excellentia hominis de Giannozo Manetti ${ }^{106}$.}

Era a expressão da confiança absoluta nas potencialidades do homem e a exaltação da sua força criadora, própria da concepção antropocêntrica humanista, que o poema de Cataldo revelava.

João de Barros, na Crónica do Imperador Clarimundo - cavaleiro romanesco que "Deus escolheu para origem dos reis de Portugal" - no cap. X, que trata da criação do príncipe, põe na boca deste o seguinte diálogo com a mãe adoptiva Grionesa: "Bem conhecido está, senhora, respondeu ele, que todas as cousas, por fortes que sejam, são ao homem sujeitas; e posto este senhorio, que sobre elas temos, e nos Deus deu, não pode aí haver alguma de tanta braveza, que os homens não vençam e tragam ao jugo da sua vontade". ${ }^{107}$.

É neste contexto ideológico que, no nosso humanismo, o catálogo das virtudes do rei adquire significado. As armas de que dispõe o homem para dominar as suas paixões são as virtudes presididas pela razão, condutora do Carro de Dürer. Este papel da razão, na orientação da vida humana, revelado por todos os humanistas, permite uma confiança absoluta nas capacidades do próprio homem e na sua realização plena como ser livre e superior. É assim que D. Jerónimo Osório, no livro III do De regis institutione et disciplina, numa expressão máxima dessa superioridade, afirma — baseado numa tradição de que Plutarco é transmissor ${ }^{108}$ - que importa ao homem, príncipe neste caso, não desarreigar de si as paixões, mas saber dominá-las e usar delas ${ }^{109}$.

Todavia um aspecto é comum à concepção destes tratados medievais e renascentistas: ambos são uma idealização da figura do governante, mediante os padrões de sensibilidade de cada época.

Quer no modelo mitificado - de que a obra do imperador Maximiliano I, Teuerdank, de 1517, com o seu prestigioso cortejo de heróis e santos de ascendência imperial, é o exemplo mais típico ${ }^{110}$ - , quer nos tratados em que se apresenta

${ }^{106}$ Vide Feritas, cit., p. 5.

107 João de Barros, Clarimundo, vol. I. Lisboa, 1953, p. 109-110.

${ }^{108}$ Vide em Plutarco, De uirtute morali, sobretudo 451 B e sqq., a reflexão filosófica sobre as opiniões dos vários filósofos neste domínio e a sua atitude - apoiada sobretudo em Platão - em favor da diversidade da alma humana, das paixões ao lado da razão, que

109 Vide Op. omnia, I, 334. 30-40. emprestam a esta um maior vigor, desde que sejam moderadas.

${ }^{110}$ Vide a descrição e intenção alegórica do poema, suas edições e traduções em francês e espanhol, em J. G. Théodore Graesse, Trésor des livres rares et précieux. Vol. VI, Dresde, 1865 , p. 106-107 (s. u. Tewerdannckh). 
o ideal do governante ligado a um modelo real, vivo - como nos tratados do Quattrocento italiano e na Institutio principis christiani de Erasmo (1516), integrada na mesma tradição, e a partir dela em todos os tratados humanistas - é permanente essa idealização na busca de um paradigma.

No entanto, o modelo teórico mais frequente, no século XVI, é aquele que nos dá do príncipe, da sua pessoa e da sua função não um retrato mitificado, mas um modelo emblemático de um ideal absoluto, para o qual deve tender. Poder-se-á mesmo afirmar que este sentido absoluto de modelo, esta convicção profunda de paradigmas ideais e de uma deontologia ética e política é um dos aspectos característicos do pensamento humanístico, imbuído, neste particular, de neoplatonismo ${ }^{111}$.

Precursoras desta atitude - e de grande interesse para a análise da imagem do príncipe nos alvores do nosso Renascimento e do sentido da sua evolução - são as palavras do Doutor Vasco Fernandes de Lucena, em resposta à carta do infante D. Pedro, que lhe pedia, "tornasse a Oração de Plínio em lingoagem":

Muitas vezes pensando nos grandes feitos dos passados Príncepes me maravilhey que, tão virtuoso, se homens em aquelle tempo couzas mui dignas de memoria acabassem, e depois ao Ceo assim fossem arrebatados, que algua sua imajem em esta nossa idade não deixassem, e por certo tão excellente se forão muitos, entre os quais Cezar como principal pode ser contado em louvados costumes e conversação graciosa, que mais pareça fingimento que história o que assim delles pellos Authores escrito achamos, quem poderia, muito poderoso Princepe, crer que em hũ mortal homem tantos louvores e tão divinas perfeiçõis coubessem, como Plínio e Marco Tulio delle escreverão, mas quando eu concidero os maravilhosos feitos do muito virtuoso, e nunca vensido Princepe El Rey D. João, vosso Padre da piadosa memoria [...] somente crerey os louvores que os sobreditos escreverão de Cezar, mas ainda me não maravilharey... ${ }^{12}$.

Apesar de integradas no elogio do rei D. João I, estas palavras, denunciadoras da idealização do chefe político, prenunciam a perspectiva de Frei Heitor Pinto, no Diálogo da Justiça, exemplificativas do ideal renascentista:

- Um desses príncipes será mais raro de achar que ave Fénix, que não há mais que uma no mundo [...]

${ }^{111}$ Cf. a este propósito Margherita Isnardi Parente, introdução à sua tradução italiana, anotada da Institutio principis christiani de Erasmo, op. cit., p. 12 e sqq.

Cf. ed. de Joseph M. Piel do Livro dos Ofícios traduzido pelo Infante D. Pedro (Livro dos Ofícios de Marco Tulio Ciceram, o qual tornou em linguagem o Infante D. Pedro, Duque de Coimbra, Coimbra, Acta Universitatis Conimbrigensis, 1948), p. XLII, (fol. 68r-68v). 
- Ainda, respondeu o teólogo, que o não haja realmente, há-o no concepto daquele que o define. Donde veio Platão a definir e descrever uma república, a mais excelente que ele imaginou, a qual nunca foi nem há-de ser. E Xenofonte, excelente filósofo e orador, condiscípulo do mesmo Platão, pintou na Pédia de Ciro um perfeito príncipe, qual ele nunca vira, nem cria que veria nunca. [...] Ambos estes dois filósofos, Platão e Xenofonte, foram discípulos do grande Sócrates, de cuja fonte beberam esta doutrina, não definiram nestas suas obras o que era, mas o que desejavam que fosse ${ }^{113}$.

E prossegue ainda, com a apresentação de obras da época em que este mesmo espírito está presente: "A estes autores imitaram em nossos tempos Tomás Morus, conde de Inglaterra, no livro da Cidade, que aí não há: e Baltasar Castelão, conde de Itália, no seu livro Do perfeito cortesão" ${ }^{\prime 14}$.

Era a justificação da utopia — que no século XVI interessou altos vultos do humanismo, Tomás Moro, Erasmo, Rabelais - e a justificação ainda para tão grande profusão de obras sobre o príncipe e a sua governação. Entre as principais, as de Erasmo, Josse Clichtove, Guillaume Budé, Johan Sturm, Thomas Elyot, Jerónimo Osório.

A preferência de Frei Heitor Pinto por uma obra tipicamente humanista como $I l$ cortegiano, em que, a par das qualidades morais e cívicas tradicionais, se dá um relevo especial a tantas outras de carácter intelectual, social e humano, adquire uma singular importância. Uma evolução na concepção do modelo de príncipe no humanismo se denuncia: a sua personalidade humana, a forma de se comportar em sociedade, a sua cultura, a sua postura, até as suas maneiras, os seus gestos, o seu semblante, entram em linha de conta na apreciação da figura do governante ${ }^{115}$.

${ }^{113}$ Fr. Heitor Pinto, Imagem da vida cristã, ordenada por diálogos, 2 vols., introdução de J. V. de Pina Martins (edição fac-similada da edição da Typographia Rollandina, Lisboa, 1843), Porto, 1984: I, “Diálogo da Justiça”, cap. IV, cit., p. 161-162.

114 Ibidem, p. 162.

115 Contrastante neste particular, é a imagem do homem, do príncipe medieval. Vide a este propósito W. Von den Steinen, Der Kosmos des Mittelalters, Bern-München, ${ }^{2} 1967$, p. 103-107 e o passo que Jean Leclercq transcreve em tradução: “les représentations de personnages ne donnent pas les traits individuels de ceux-ci; elles ne veulent pas être des portraits exacts: un empereur, par exemple, n'est pas montré pour lui-même, tel qu'il est physiquement, mais dans son rôle; ce qui importe n'est pas sa personne seule, mais la realité qu'elle représente" (Cf. Dictionnaire de spiritualité, art. "Humanisme et Spiritualité". Tom. 7. Paris, 1968, p. 970). O sublinhado é nosso. 
O próprio Erasmo que, na Institutio principis christiani ( $L B$, IV. 561 A), afirma que os dotes físicos, a formosura do príncipe pouco interesse têm para a função real, no seu Ad Philippum panegyricus ( $L$ B., IV. 526 D) não resiste a tecer este elogio ao pai de Carlos V: "In te rara quidem corporis species, sed dignus erat tam bello domicilio animus longe pulcherrimus".

D. Jerónimo Osório, no De regis institutione et disciplina, inspirado em Aristóteles (Política, IV, 1290 b 4-5) ou mesmo em Heródoto (Historiae, 3. 20), refere o exemplo de povos antigos, tais como os Persas ou os Espartanos, que valorizavam acima de tudo a excelência física na escolha dos seus governantes (I. 368 . 50 e sqq.). Muito embora o nosso humanista se coloque, neste passo, na linha de Erasmo, não deixa de elogiar a atitude destes povos antigos, reveladora da preocupação da excelência e perfeição, indispensáveis no príncipe (I, 369.20).

Inácio de Morais, na Oratio panegyrica ad inuictissimum Lusitaniae Regem diu Ioannem tertium, exprime de forma acabada este mesmo espírito ${ }^{116}$.

D. Sebastião, para Camões «maravilha fatal da nossa idade», é por Diogo de Teive assim retratado, na sua Institutio, que apresentamos em tradução de Francisco de Andrade (op. cit., p. 94-95):

Quem isto imaginar com diligência,

E por seus olhos vir a formosura,

E o grande resplendor daquelle rostro,

Que às Estrelas parece similhante,

Quando a noite se mostra mais serena,

Entender poderá bem claramente,

Que elle por Deos foi dado a este Reino,

Porque em todos bens, glorias, e honras

o accrescente, encha, honre, e enriqueça...

Este ideal de perfeição física e moral que o rei deve encarnar, no mais alto grau, transparece de forma clara na poesia da época ${ }^{117}$. Gil Vicente chama a D. João III

${ }^{116}$ Vide ed. em fac-simile, feita pelo exemplar da Bibl. Municipal do Porto, publicada no IV Centenário do estabelecimento definitivo da Universidade em Coimbra, fol. A iij.

117 Albin E. Beau, "A realeza na poesia medieval e renascentista portuguesa". Sep. do Boletim de Filologia [15-17 (1954-1958)]. Lisboa, Centro de Estudos Filológicos, 1959, p. 1-97. Vide também o nosso estudo "O tema da morte do príncipe D. João na poesia quinhentista" in Diogo de Teive, Tragédia do príncipe João, sobretudo, p. 47-51, onde se encontram os elogios, tanto ao gosto humanista, do príncipe D. João, pai de D. 
"o mais fermoso Rei / que ha na face da terra"

Garcia de Resende, ainda antes da publicação de Il cortegiano, traça do mesmo monarca um retrato verdadeiramente significativo deste ideal:

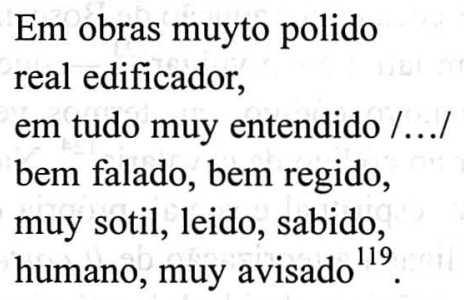

Este relevo dado ao porte físico e ao aspecto exterior do indivíduo vai culminar, em finais do séc. XVI, com a obra de J. Huarte de S. Juan, Examen de ingenios para las sciencias (1575), dedicada a Filipe II, que trouxe um contributo novo ao estudo da psicologia diferencial ${ }^{120}$ e teve grande divulgação no mundo culto da época. Este autor, depois de afirmar nos capítulos XI e XIV da sua obra que a arte de governar diz respeito à imaginação, ocupa-se no capítulo XVII dos caracteres daquele que se destina ao ofício de rei. Neste capítulo toma uma posição digna de nota:

Ser el rey hermoso y agraciado es una de las cosas que más convida à los súbditos quererle y amarle, porque el objeto del amor dice Platon que es la hermosura y buena proporcion, y si el rey es feo y mal tallado, es imposible que los suyos le tengan aficion, ántes se afrentan de que un hombre imperfecto $\mathrm{y}$ falto de los bienes de la naturaleza los venga à regir y mandar ${ }^{121}$.

É que, como dirá num contexto bem diverso, António Ferreira pela boca de Alexandre, na comédia Do Fanchono, "a fermosura, assi como representa mays

Sebastião, expressos de forma semelhante aos dirigidos, a um século de distância, ao príncipe D. Afonso, filho de D. João II: a sua beleza, o esplendor da sua formosura, a par das suas virtudes, renome e glória.

${ }^{118}$ Gil Vicente, Tragicomédia pastoril da Serra da Estrela in Obras Completas, IV, Lisboa, 1942-1944, p. 195.

119 Crónica de dom João II e miscelânea. Ed. de Joaquim Veríssimo Serrão. Lisboa, 1973, p. 375.

${ }^{120}$ Conhecido é o facto de Miguel de Cervantes nela se basear para construir as personagens de D. Quixote e Sancho Pança.

${ }^{121}$ Vide Doctor Juan Huarte De San Juan, Examen de ingenios, in Biblioteca de autores españoles, tomo LXV (Obras escogidas de filósofos). Madrid, 1922, p. 487. Pudemos consultar também uma tradução francesa desta obra: L'examen des esprits pour les sciences de Jean Huarte Medecin Espagnol. Nouvellement traduit suivant l'ancien original. À Paris, chez Jean de Bouc, 1645, (o passo transcrito: p. 588). 
aquella semelhança de Deos, assi tem huma força natural, com que afeiçoa os olhos \& as vontades" ${ }^{\prime 22}$.

É, no entanto, à obra de Baldassare Castiglione, publicada em 1528 com dedicatória a D. Miguel da Silva - que mereceu uma tradução de Boscán, El cortesano, numerosíssimas edições e traduções em latim e em vulgar ${ }^{123}$ - que cabe o mérito de ter proposto, definitivamente, um novo código, em termos verdadeiramente humanistas, susceptível de se sobrepor ao código da cavalaria ${ }^{124}$. Na verdade, a dignificação da realidade humana, física, espiritual e social, própria do humanismo renascentista, a que directamente está ligada a teorização de $I l$ cortegiano, explica a permanência de elementos novos na definição do ideal do príncipe.

Não é sem motivo que Dürer coloca nas rodas do seu Carro triunfal a magnificentia, o honor, a dignitas, a gloria. É apoiado nelas que o triunfo avança. Estas virtudes não tinham significado no ascetismo medieval - que caracterizava a tratadística de então, a não ser num plano exclusivamente divino, que lhes retirava o verdadeiro sentido que no humanismo adquirem.

A análise exaustiva do conceito de glória nos autores da Antiguidade e nos da época medieval, em particular dos castelhanos, feita por M. R. Lida de Malkiel ${ }^{125}$, faz-nos entender a verdadeira dimensão do pensamento colectivo da época.

A síntese mais expressiva do ideal humanista de glória, no nosso Renascimento, é-nos dada por D. Jerónimo Osório, nas suas obras. No De gloria (1549), muito anterior ao De regis institutione et disciplina (1572), faz o elogio da glória, incen-

122 Vide a edição portuguesa com tradução francesa de Adrien Roïg, que refere a inspiração platónica deste passo, La comédie de Bristo ou l'entremetteur d'António Ferreira, Paris, 1973, p. 182.

123 Vide exemplar da B.G.U.C. (cota R-8-14): Baltasar Castiglione, El cortesano, Trad. por Boscan en nuestro vulgar castellano. Anvers, 1561. Sobre as muitas edições e traduções de Il Cortegiano, vide J. G. Théodore Graesse, Trésor de livres rares cit. Tome II. Dresde, 1861, p. 65-66.

${ }^{124}$ A exaltação da beleza do corpo humano, dos dotes naturais de príncipes, princesas, jovens e donzelas surge na poesia latina dos séculos XI e XII e é um lugar-comum das novelas medievais (cf. E. R. Curtius, Literatura europea y Edade Media Latina, 2 vols. México, 1981: I, p. 260-262). No entanto, como observa Peter Burke (The Italian ..., p. 196-198), há uma mudança de ênfase nos autores do Renascimento, tais como Lorenzo Valla, Pietro Pomponazzi, Alberti, Policiano, Giovanni Pico della Mirandola.

${ }^{125}$ Maria Rosa Lida de Malkiel, L'idée de la gloire dans la tradition occidentale. Antiquité, Moyen Âge occidental, Castille, Paris, 1968 (tr. franc.), p. 93-94. 
tivo e exemplo de virtudes ${ }^{126}$. Nos dois primeiros livros deste tratado, em diálogo com os seus companheiros de Bolonha, apresenta a atitude que caracterizou genericamente o pensamento medieval, que vai ser rebatida a partir do livro III até ao V. É deste último o passo que transcrevo, onde o humanista conclui (I, 229, 50-60): Hoc etiam modo sapientiae, continentia, aliarumque uirtutum omnium fructus et angustis finibus et exiguo uitae spatio circumscriptus. At fama iustitiae, fortitudinis, liberalitatis, continentiae, et omnium denique uirtutum, non paucis, sed omnibus, non modo suis, sed etiam exteris, non una tantum aetate, sed in multa saecula, atque prope infinita consulit., "... E mais ainda, o fruto da sabedoria, da temperança e de todas as outras virtudes limita-se à estreiteza das fronteiras e à curta duração da existência. Porém a fama da justiça, da fortaleza, da liberalidade, da moderação, enfim de todas as virtudes, não a poucos aproveita, mas a todos, não só a nacionais como a estrangeiros, e perdura não apenas por uma geração, mas por muitos séculos, quase infinitamente".

Note-se que na enumeração das quatro virtudes cardeais, neste texto, a prudentia é substituída pela liberalitas. Tal como Erasmo, na Institutio principis christiani (L. B.., IV, 595 A: "Cum propria bonorum Principum laus sit benignitas ac beneficentia"), a glória do príncipe anda ligada à sua liberalidade, pelo que D. Jerónimo Osório lhe dá preferência.

Mas é sobretudo na dedicatória deste tratado a D. João $\operatorname{III}^{127}$ e na do De regis institutione et disciplina a D. Sebastião ${ }^{128}$ que este conceito de glória humanista se aplica à dignidade régia. Bem expressivo, neste sentido, é também o passo seguinte da Doutrina de Lourenço de Cáceres ao Infante D. Luís:

O Príncipe logo assi virtuozo, nunca cessará, comedindo como acrescente o bem da sua Republica, e a glória da sua fama, que a estes dois fins há de endereçar todos seus pensamentos ${ }^{129}$.

${ }^{126}$ Vide, e. g,., o longo passo do livro V (Op. omnia, I, 229.30 - 230. 10) onde - tendo por certo em mente os ataques de Maquiavel - afirma que a glória, apoiada na virtude, deve ser cultivada entre os cristãos, empenhados na salvação colectiva do género humano.

127 Op. omnia, I, 116-118. Cf. e. g., 118. 30-40 Singularis enim tuae probitatis exemplis docuisti /.../ iustitiam, aequitatem, mansuetudinem, beneficentiam, religionem, gloriam imortalem efficere (o sublinhado é nosso).

${ }^{128}$ Vide Op. omnia, I, 259. 10-20: Accedit etiam regia disciplina, et magistri probitas, et paedagogi sapientia, et reliquorum hominum nobilium, quibus uteris, uirtus et integritas, quorum monitis et exemplis, credo te mirandum in modo, studio immortalis nominis incitari (o sublinhado é nosso).

${ }^{129}$ Vide Bento Jozé de Sousa Farinha, Filozofia de príncipes, I, cit., cap. XVI, p. 50. 
Significativos são também os termos com que termina este tratado:

Que nosso Senhor prospere, a acrescente com novos Títulos de honra, e justos triumphos de victorias a seu serviço ${ }^{130}$.

Este conceito humanista da glória permanece nos autores do século XVI ligado aos conceitos de honor (fama, laus), dignitas, magnanimitas, magnificentia.

O conceito de magnanimitas - termo que substituirá, ao longo da Idade Média, as expressões clássicas magnus animus, magnitudo animi, preferidas por Cícero ${ }^{131}$ - assimilado no latim cristão ao conceito de humilitas, vai ser repensado pela primeira vez à luz dos princípios aristotélicos por Santo Alberto Magno. Mas a conciliação entre estes dois conceitos, por assim dizer antagónicos, da filosofia antiga e da moral cristã cabe a S. Tomás de Aquino que, em termos de espiritualidade medieval, faz a síntese do problema então debatido ${ }^{132}$.

No século XVI, magnanimitas e magnificentia tornam-se sinónimos, conclui Margaret Greaves, no seu estudo The blazon of honour. A study in Renaissance magnanimity $^{133}$.

O Dicionário de Jerónimo Cardoso ${ }^{134}$ regista para o seu termo magnanimitas o significado de 'a grandeza de alma' e para magnificentia 'a grandeza', o que deixa transparecer similitude conceptual que poderá favorecer um certo deslize a nível ideológico entre as duas noções. O que não há dúvida é que também entre nós, e no humanismo em geral, o conceito de magnanimitas corresponde ao aristotélico. É a magnanimitas uma espécie de ornamento das virtudes — porque está na origem

130 Ibidem, p. 66-67.

131 O termo magnanimitas é um neologismo forjado por Cícero a partir de $\mu \in \gamma \alpha \lambda \circ \psi \psi \psi \chi \chi i \alpha$, virtude da moral estóica que engloba as virtudes $\alpha$ $\nu \delta \rho \in i \alpha$ e $\kappa \alpha \rho \tau \in \rho i ́ \alpha$. Cf. a divisão das virtudes, segundo Panécio, feita por Cícero em Part. 76-78. O termo magnanimitas, criado por Cícero, foi contudo usado por ele uma única vez, (Off. I. 152); preferia as expressões magnus animus, magnitudo animi. Vide R.-A. Gauthier, O.P., Magnanimité. L'idéal de la grandeur dans la philosophie païenne et dans la théologie chrétienne, Paris, 1951, p. 158-169.

${ }^{132}$ R-A. Gauthier, O. P., Magnanimité cit, p. 445 e sqq. e 489 e sqq.

133 New York, Barnes \& Noble inc., 1964, p. 22.

${ }^{134}$ Vide Hieronymi Cardosi Lamacensis Dictionarium ex Lusitanico in Latinum sermonem, Ullissypone, Ex officina Joannis Aluari typographi regia, MDLXII (tem junto a dedicatória de Sebastião Stockhamer ao rei D. Sebastião datada de Coimbra, 1569 e ainda o privilégio real, lavrado por Baltasar da Costa, datado de Lisboa, 1569). Cf. p. 117v. 
delas - digno da maior honra, que é sempre a recompensa das próprias virtudes ${ }^{135}$.

Define-a nestes termos significativos já o nosso tratadista Diogo Lopes Rebelo, no seu De republica gubernanda per regem ${ }^{136}$ : Magnanimitas est una uirtus per quam quis appetit magnos honores sibi debitos et haec uirtus summe necessaria est regi _ "A magnanimidade é uma virtude pela qual alguém anseia por grandes honras a si devidas. Esta virtude é extremamente necessária ao rei”.

Também a magnificentia, até então quase sempre assimilada à ideia de benefício e à virtude da liberalidade, especifica o seu sentido à luz da tradição clássica. É exemplo disso a referida obra de Diogo Lopes Rebelo ${ }^{137}$ : Liberalitas, secundum Aristotelis sententiam, in quarto libro suae Moralis Philosophiae, est uirtus moralis, et differt a magnificentia quae est etiam moralis, uirtus in hoc quia liberalitas est circa paruas pecunias dandas recipiendasque; magnificentia est circa magna... " - A liberalidade, na opinião de Aristóteles, no quarto livro da sua Filosofia Moral, é uma virtude moral e difere da magnificência, que é também uma virtude moral, neste aspecto: enquanto a liberalidade consiste em dar ou receber quantias grandes ...".

Mais adiante ${ }^{138}$, justifica este autor a necessidade da magnificência real não só como recompensa de méritos ou recurso a necessitados, mas mesmo como prática em relação "a estranhos, peregrinos e estrangeiros" (extraneis et aliis peregrinis et alienigenis" "para o bendizerem e pregarem a sua magnificência nas nações estrangeiras" (ut illi bona dicant et praedicent regis magnificentiam apud exteras nationes).

A virtude aristotélica da magnificentia (EN 1122 a - 1123 a 30), que convida a dar todo o brilho possível, grandeza e prestígio ( $E N 1122$ b 30) às funções nobres e distinções, informa o conceito renascentista de magnificentia.

D. Jerónimo Osório, no De regis institutione et disciplina (I. 537.46 e sqq), ao definir o munus et officium Regis, dirá que todos os trabalhos e canseiras que lhes são inerentes se justificam em função do esplendor e magnificência real.

A magnificentia adquire assim um relevo especial ao lado da maiestas, a majestade, ligada muitas vezes à expressão externa do poder.

Se o título de Majestade teve entre nós, durante a Idade Média e até ao Renascimento, uma coloração religiosa, pode afirmar-se que é precisamente "no

\footnotetext{
${ }^{135}$ Vide E. N., 1123 b $25-1124$ a 5.

${ }^{136}$ Cf. cap. VII, ed. cit., p. 96).

${ }^{137}$ Cf. cap. IX, ed. cit., p. 112-113.

138 (Ibidem p. 116-117).
} 
início do mundo moderno que se assiste à reivindicação do título de Majestade pelos diversos monarcas"139.

No entanto, tal designação "é particularmente significativa por permanecer única durante muito tempo, antecipando-se à fórmula do tratamento convencional", nas Obras do condestabre D. Pedro e na de Gil Vicente, Divisa da Cidade de Coimbra (1527), com respeito a monarcas portugueses ${ }^{140}$.

Isto sem esquecer que o título de majestade, concedido em Roma à república, ao povo romano e aos seus imperadores, foi largamente utilizado por Gil Vicente no tratamento de reis e imperadores das tragicomédias Amadis de Gaula e Dom Duardos ${ }^{141}$.

Mas estes autores não estão isolados. Diogo Lopes Rebelo, ao dedicar ao rei D. Manuel o seu tratado De republica gubernanda per regem (1496), assim se lhe dirige $^{142}$ : Accipiat, igitur, potentissime ac inuictissime rex, Vestra Regia Majestas hoc paruum opus Vestro nomini dedicatum... .

Já antes, contudo, este autor tinha exprimido o alcance e distinção deste tratamento, nestes termos ${ }^{143}$ : Advertendum est etiam quod tanta est regiae majestatis dignitas et excellentia, ut posito quod rex sit iniquus et injustus, semper tamen a suis subditis debet in honore praeferri, "Deve-se notar ainda que é tamanha a dignidade e a excelência da majestade real, que, embora o rei seja iníquo e injusto, sempre deve ser preferido nas honras pelos seus súbditos".

Teremos de esperar, contudo, até D. Sebastião para assistirmos à apropriação por um rei português do título de Majestade. Foi este, aliás, o tratamento com que o agraciou seu tio Filipe II, na célebre entrevista de Guadalupe. A este título associa também D. Sebastião a sua coroa fechada, até então atributo de imperadores ${ }^{144}$.

O próprio aio de D. Sebastião, D. Aleixo de Meneses, ao tecer considerações sobre a sua educação, critica nos mestres a intenção de apartar "os príncipes da affabilidade e communicaçam dos seus vassallos" para "acrescentar com severidade o

${ }^{139}$ Vide Martim de Albuquerque, O poder político no Renascimento português, Lisboa, 1968 , p. 360.

${ }^{140}$ Cf. Albin E. Beau, "A realeza na poesia medieval e renascentista portuguesa”, Separata do Boletim de Filologia 15-17 (1954-1958) 1-97: p. 45-46.

141 Ibidem.

142 Cf. ed. cit., p. 172.

143 Ibidem, p. 164-165.

${ }^{144}$ Vide Martim de Albuquerque, O poder politico no Renascimento português, p. 358-360. 
respeito e veneraçam proprio da Magestade Real". No entanto, a sua preocupação manifesta-se ainda, neste particular, ao contrapor tal atitude ao inconveniente de, "com as licenças da sua pouca idade", se descuidarem "nas cerimonias, e tratamento da Majestade real..."145.

D. Jerónimo Osório, no De regis institutione et disciplina, dirigido ao mesmo príncipe, assim se pronuncia (I, 440.43-46): Regis autem Maiestas, et amplitudo sublimior est, quam ut quisquam ad illius aequalitatem, et similitudinem adspirare queat — "É que a majestade e a grandeza do rei a tal ponto se elevam, que pessoa alguma poderá aspirar a igualar-se ou a parecer-se a ele"146.

Num passo seguinte, Osório ao aludir à majestade régia — de forma semelhante a Erasmo, que a considera apanágio apenas de príncipes, que seguem no seu governo o exemplo de Deus (L. B. IV. $587 \mathrm{~A}$ ) - expõe, nestes termos, a opinião de pessoas avisadas (I, 455.51-54): Videbant enim, Regiam Maiestatem non solum esse Dei prouidentia constitutam sed singulari etiam illius ope, et beneficio conseruatam, "É que eles bem sabiam que a Régia Majestade não só foi conferida pela providência divina, mas também conservada pelo seu único auxílio e pela sua graça".

A dimensão sobrenatural que este título encerra para D. Jerónimo Osório é sem dúvida significativa da sua posição de doutrinador pós-tridentino, empenhado em sublinhar a missão divina de um príncipe, mas ainda reveladora da sua consciência cívica, da sua preocupação em apontar ao jovem rei a responsabilidade e a grandeza do seu ofício. Assim, este retomar do cristocentrismo erasmiano não abranda o tom encomiástico com que o nosso autor se refere à maior dignidade régia. Antes a eleva a um plano superior, o divino. A confirmar esta asserção está o longo passo que se encontra a introduzir este tratado: Op. Omnia I, 255.46-256.43.

Já no Quattrocento italiano, o conceito de majestade, de magnificência, no sentido moderno, aparece nas obras de humanistas como Platina, Pontano, Majo ${ }^{147}$. Destes autores referimos, como exemplo significativo, os escritos de Giovanni Pontano, cujos títulos são por si elucidativos: De magnificentia, De splendore, De liberalitate, De beneficentia, entre outros. No seu De principe (ad Alphonsum

145 Vide Fala de D. Aleixo de Menezes à Senhora Dona Catherina, e ao Cardeal D. Henrique, sobre a educaçam do Senhor Rey Dom Sebastiam, in Filozofia de Príncipes, I, p. 78-79.

${ }^{146}$ Cf. supra n. 64. Exprime uma ideia semelhante, em contexto idêntico, Erasmo na Institutio principis christiani, L.B., IV. 600F-601A.

${ }^{147}$ Vide a este propósito, Felix Gilbert, "The humanist concept of the prince and The Prince of Machiavelli”, The Journal of Modern History 11.4 (1939) 449-483: p. 465-466. 
Calabriae ducem) tece considerações sobre a maiestas - que se funda sobre a fama - que chegam ao pormenor de especificar os trajos, os tecidos e suas cores, a forma de usar o cabelo, a palavra, o gesto adequado, a voz ${ }^{148}$.

A importância que a maiestas adquire na caracterização do príncipe leva Giuniano Majo a compor um tratado intitulado De maiestate (1493). Entre nós, a grandiosidade, o esplendor, associados à figura do governante como símbolo da pátria, revela-se de um modo particular nos grandes cerimoniais, nas aclamações ou coroações - estas últimas não existentes em Portugal —, nas entradas de personalidade de relevo, por altura de casamentos de príncipes ou em celebrações de acontecimentos importantes. É sobretudo a partir do reinado de D. João II que, no dizer de Garcia de Resende, "era muyto cerimonial"149, e no de D. Manuel, que a imagem do poder régio se manifesta através do aparato externo de que se rodeia a figura do rei e a sua corte, a que dão brilho os elementos exóticos provenientes do mundo oriental. Não faltaram ocasiões entre nós, neste reino lusitano, "quasi cume da cabeça da Europa toda" deste ideal de grandeza. A literatura da época é bem o testemunho disso.

No entanto, as qualidades humanas do governante como pater patriae ${ }^{151}$ são sobremaneira valorizadas: a humanidade, a clemência, a liberalidade são enaltecidas.

João de Barros, no prólogo da Crónica do Imperador Clarimundo, afirma: “Amor, favor e temor, rei mui poderoso, príncipe de justiça, tem tanta força em todas as cousas,

${ }^{148}$ Ioannis Iouiani Pontani /.../ Opera omnia (ed. cit. Basileia, 1538), I, p. 178. Neste primeiro volume se encontram também os escritos aqui referidos.

149 Vide o Prólogo de Crónica de dom João II de Garcia de Resende (ed. conjunta com a Miscelânea, conforme a de 1798, com introdução de Joaquim Veríssimo Serrão. Lisboa, 1973), p. XXI. O gosto deste autor palaciano pela descrição da pompa e circunstância de que se rodeava a figura do rei nos cerimoniais revela-se a cada passo: e.g., ibidem, cap. 26 ("Das Cortes que el Rey fez na Cidade de Euora, onde lhe deram obediencias, e menajens"), p. 32-33; cap. 79 ("Da cerimonia com que el Rey fez o marquez de Villa Real"), p. 118-119. ${ }^{150}$ Cf. Luís de Camões, Lusíadas, III, 20.

${ }^{151} \mathrm{O}$ título de pater patriae, com larga tradição na literatura latina (e. g. Séneca, Cl. 1.14.2; Musónio Rufo, fr. 8; Plínio-o-Moço, Pan. 84.6 e Plínio-o-Velho, que tem por ele certa preferência) é frequentemente dado aos nossos monarcas, pelos tratadistas, moralistas e humanistas em geral, quer em latim, quer em vulgar. João de Barros, Panegírico do rei $D$. João III (in Panegíricos. Texto restituído, prefácio e notas por M. Rodrigues Lapa, Lisboa, 1937, p. 49), evoca mesmo a autoridade de Séneca, que privilegia este modelo familiar de governante. Também se usava em latim, a fórmula parens patriae (e.g. Valério Máximo, 9. 11 ext. 4; Séneca, Octauia, 472; 490; 495) que D. Jerónimo Osório emprega no prefácio do De nobilitate ciuili (Op. Omnia I. 2.10-20), ao referir-se a D. João III. 
que nenhuma se pode fazer sem algum deles e às vezes com todos" ${ }^{\prime 152}$.

E no seu Panegírico de D. João III assim se exprime: "Vossa Alteza sempre temperou sua real gravidade com muita humanidade e clemência, de tal maneira soube ajuntar cousas em si tam diferentes, que nem por ser muito grave leixa de ser amado. Não se deve louvar no príncipe condição áspera /.../ Também se deve guardar o príncipe que não seja tão brando e de boa condição, que se perca o acatamento devido à Majestade real" ${ }^{\text {"153. }}$.

Neste contexto de valorização humana, em que a figura do príncipe se integra, a educação tem o maior alcance. Na verdade, o aspecto educacional que é excepcionalmente objecto de atenção dos tratadistas medievais vai tornar-se aspecto fulcral e orientador de produção renascentista. O Speculum principum, como género, dá lugar ao verdadeiro tratado de educação de príncipes.

Erasmo, no De pueris statim ac liberaliter instituendis afirma: Fons enim omnis uirtutis est diligens ac sancta educatio (L.B. I, $491 \mathrm{E})$.

Todos os nossos humanistas participam nesta crença. Diogo de Teive dirá na sua Institutio Sebastiani Primi ${ }^{154}$ :

Se se achar por ventura huma tão forte,

Tão dura natureza, hum tal animo,

E tão mal á razão obediente,

Que não sofra doutrina, nem a aceite,

Contra este tambem val a diligencia,

A doutrina do Mestre, e o bom cuidado,

Que em fim o grão trabalho acaba tudo

Não ha bruto animal tão indomavel,

Que com arte não mude a natureza

Porque inda que ella tenha grande força,

Resistir nunca póde ás da industria,

Mas antes lhe ficou sempre subjeita.

O homem apenas atinge a perfeição da sua natureza se for instruído e educado. É em termos de pessoas mais do que de instituições que a política interessa aos

152 João de Barros, Crónica do imperador Clarimundo, I, Lisboa, 1953, p.1.

153 Idem, Panegírico do rei D. João III, in Panegíricos, Lisboa, 1937, p. 9.

${ }^{154}$ Cf. ed. e trad. cit., p.127. 
homens. O ideal de perfeição política, ligado ao conceito da personalidade individual plena, dependente da formação do príncipe com um sentido de totalidade, vai ser a tónica do humanismo renascentista, herdeiro do ideal da paideia grega e do humanismo politicista, transmitido pelos autores da época helenística ${ }^{155}$.

$\mathrm{Na}$ verdade, esta importância dada à educação do príncipe provém da crença humanística no saber, como fonte de perfeição: dele vão depender as leis, que regulam a vida do estado, a escolha dos conselheiros e ministros, a prosperidade ou ruína de todo um reino. Assim se pode afirmar que, se a especificidade e originalidade deste género literário se não encontrasse na forma de tratar a matéria com um cunho verdadeiramente humanista, na perfeição estilística e formal da prosa, um aspecto essencial seria de referir: a relevância da pedagogia sobre a problemática política, o carácter paradigmático sobreposto ao conteúdo programático.

Sendo assim, e tratando-se de um domínio em que os topoi são frequentes tem que ser posto em destaque um aspecto comum em todos os tratados desde o Quattrocento italiano: o esforço para adaptar as ideias da filosofia antiga às condições de um estado moderno. Um mesmo fundo comum de leituras - Platão, Aristóteles, Isócrates, Xenofonte, Plutarco, Cícero, Quintiliano, os poetas clássicos - inspira os humanistas, e se existem divergências, ideias ou pontos de vista diferentes entre eles, desde um Francesco Patrizi ${ }^{156}$ a um Diogo de Teive ou D. Jerónimo Osório, todos concordam sempre no essencial: na definição de um programa de educação completo, que prepara o príncipe para a sua futura tarefa de governante.

Os tratados medievais, ao sublinharem a importância da sabedoria do rei, faziam-no sempre em termos de ascese e não em termos de aquisição de conhecimentos, como base do sucesso na governação.

${ }^{155}$ Cf. Platão, R. (428 e - 429 a); Pol. (292 e) e Aristóteles, Pol. (1275 a - 1278 b; 1283 b - 1284 b 34). Estes dois filósofos, na sua teorização, valorizam a personalidade e a superioridade moral do governante, de que Isócrates e Xenofonte, nas suas obras, apresentam o modelo.

${ }^{156}$ No que se refere ao pensamento político-pedagógico, não pode ser descurada a importância das obras de Francesco Patrizi, Senense, De institutione reipublicae e De regno et regis institutione, em nove livros - para não falar de Bartolomeo Platina com o De optime ciue e o De principe ou de Giovanni Pontano com o De principe - que mereceram, a partir da segunda metade do séc. XV, numerosíssimas edições e traduções. Estas obras contribuíram, sem dúvida, muito antes de Erasmo, para firmar na Europa, abandonada a temática das relações entre papado e império, os novos horizontes de uma política humanística, fundada na tradição platónica-aristotélica. (cf. G. Saitta, Il pensiero italiano nell'Umanesimo e nel Rinascimento, I, Bologna, 1949, p. 361-367). 
Entre os nossos tratadistas, Diogo Lopes Rebelo não é sensível ainda à importância da educação na formação régia. Será Fr. António de Beja, na sua Breve doutrina e ensinança de príncipes $^{157}$, o primeiro a dar-lhe demorada atenção e a referirse em particular à educação de um príncipe, o jovem D. João III, e aos seus ilustres mestres ${ }^{158}$ : "Avendo em sua pequena hidade, por mestre, hũ esteo da fe, Calçadilha, e sendo ho Senhor servido privar Vossa Alteza deste, vos socçedeo, em hidade mais crescida, ho sapientíssimo doctor Luys Teixeira, a quem, alem do direyto humano e sagradas leys, as duas lingoas, grega e latina, se non esconderom."

Da educação deste rei nos fala mais pormenorizadamente a Crónica de D. João III de Francisco de Andrade: falecido o seu primeiro mestre, D. Diogo Ortiz de Vilhegas (Calçadilha), o ensino do príncipe é entregue ao doutor Luís Teixeira, de quem Andrade tece os maiores elogios como jurista famoso e discípulo de Ângelo Policiano. Prossegue então: "deste ouuio o principe epistolas de Ouuídio, alguma cousa de Plínio, e de Tito liuio, e principios de grego; e para ter tambem algum conhecimento dos termos das leis, pois cos homens praticos nellas auia de ministrar justiça a seus vassalos, passou com ele á instituta." ${ }^{159}$.

O relevo dado ao cultivo das letras, no paço de D. Manuel, a educação ministrada não só a príncipes mas a moços fidalgos que o habitavam - entre os quais se contava o grande humanista Damião de Góis - se não revelou a perfeição dos dotes intelectuais do futuro monarca D. João III, criou nele o gosto pelas ciências do espírito, pelas artes liberais. Além da fundação do Colégio das Artes, escolheu humanistas de renome para educar seus irmãos, tais como Aires Barbosa, André de Resende, criou os Colégios belemitas da Costa e Penhalonga, onde foram educados o infante D. Duarte, seu filho, e D. António, o futuro Prior do Crato.

Todos os tratados de educação de príncipes contemporâneos, como o de Francisco de Monzon, ou os posteriores, dedicados a D. Sebastião, cantam com

${ }^{157}$ Cf. Primeira Parte: "Da Sabedoria”, maxime, cap. III-VIII (ed. cit., p. 119-131). Este último tem o título expressivo: "Em que manifesta que erram os que dizem os reys nam teerem necessidade de letras mas de forças pera defender o reyno".

158 Ibidem, p. 128-129.

159 Vide Francisco d' Andrada, Chronica do muyto alto e muyto poderoso Rey destes Reynos de Portugal D. João o III deste nome (P. I; cap. 3), I, Coimbra, 1796, p. 8. Sobre a educação de D. João III, vide também Frei Luis de Sousa, Annaes de ElRey Dom João Terceiro (P. I, liv. I, cap. 2), ed. com prefácio e notas de Rodrigues Lapa. I, Lisboa, 1951, p. 10. 
orgulho esta época brilhante da cultura nacional ${ }^{160}$. Mas já Garcia de Resende, na Crónica de João II, alude à educação deste rei menino, iniciada logo que ele atingiu o uso da razão, nos termos seguintes: “...e tanto que teve entender lhe ordenou logo elRey seu pai pessoas virtuosas, prudentes e muy examinadas que delle tivessem cuidado, e que fossem taes de que podesse tomar boa doctrina, e lhe deu bons mestres, que o ensinassem a ler, rezar, e latim, e escrever, e assi moços bem ensinados, pera se criarem com elle, e o servirem..."161.

Esta era a educação elementar, descrita com pormenor por Diogo de Teive, na sua Institutio Sebastiani Primi: a formação religiosa, em simultaneidade com a intelectual $^{162}$, a exercitação do corpo ${ }^{163}$ e a aquisição de bons hábitos ${ }^{164}$.

Era a lição de Quintiliano e Plutarco que Teive, não só na Institutio como nas Sententiae segue de perto; isto sem esquecer Xenofonte, de quem traduz a Ciropedia, e os representantes do pensamento platónico-aristotélico, que informam a pedagogia humanística.

Antes de Teive, e a abrir-lhe caminho, inspiram-se nestes autores os pedagogos do Quattrocento, o próprio Erasmo e os humanistas em geral.

Mas atentemos na análise da Institutio Sebastiani Primi e no pensamento pedagógico do humanista bracarense: Teive chega mesmo a precisar a idade de sete anos para o começo da aprendizagem ${ }^{165}$. Aspectos curiosos da sua obra são o sentido da maturação presente no plano de estudos, a desenvolver segundo a idade do educando ${ }^{166}$, e ainda

${ }^{160}$ Vide Francisco Monzon, Princepe Christiano (Libro primero d'l espejo del prícipe christiano: que trata como se ha d'criar un principe desde su tierna niñez). Lisboa, Luís Rodrigues, 1544, cap. XXII, dedicado à política cultural do rei D. João III.

${ }^{161}$ Garcia De Resende, Crónica de dom João II e miscelânea, cap. III "Da criaçam do Principe", p.3.

${ }^{162}$ Vide ed. cit., p. 126-127 e sqq.

${ }^{163}$ Ibidem, p. 132-141.

${ }^{164}$ Ibidem, p. 129-131 e passim.

${ }^{165}$ Ed. cit., p. 152-153: Septenus annus aptus esse traditur/Docto Magistro... "Depois que ao septimo anno o moço chega, / Já convém que ao Mestre seja entregue...”. Cf. Quintiliano, Inst.Orat. I, 1.15.

${ }^{166}$ Ibidem, e.g., p. 156-157: ...aetas ut suos habet gradus/ Sic rerum, et ipsa uelut parens scientia, / Quam facili, et apto perdocebit ordine/ Prudens Magister. "Porque ass̃ i como tem seus gráos a idade,/ Asstambem os tem a sapiencia,/ A qual he como mãi das cousas todas./ E esta póde ensinar o douto Mestre,/ Se boa ordem tiver sem grão trabalho." 
o relevo dado a aspectos psicológicos como a motivação e a emulação ${ }^{167}$.

Assinalável a importância que assumem, não só em Teive, mas em todos os humanistas as artes liberais e o ensino da história em particular, por ser esta disciplina considerada reveladora das experiências passadas e cheia de lições para o futuro ${ }^{168}$. Diogo de Teive aconselha ao príncipe a leitura de fábulas de animais como a formiga, a cigarra, a abelha mestra, exemplos de ética sociopolítica ${ }^{169}$. Aconselha ainda as fábulas de poetas e as histórias maravilhosas de príncipes passados de outros tempos, que são agradáveis e dão exemplos de virtude ${ }^{170}$. Aqui se insere o pensamento de Jorge Ferreira de Vasconcelos, manifestado no prólogo do seu Memorial das proezas da segunda Távola Redonda, romance de cavalaria que dedica a D. Sebastião. Referindo-se à sabedoria, assim se exprime: "Esta, falando de si mesma diz. Per mim governam os príncipes. A qual sendo hum conhecimento de cousas divinas e humanas a Príncipes sobre todos necessário, que nam se alcança, salvo lendo e vendo muyto [...] achey a materia heroyca mais apropriada a todo real engenho, por nella se tratar qual deve ser ho varão per fama conhecido sobre as estrelas..."171.

Não é este, contudo, o ponto de vista de Frei Amador Arrais, que escreve já depois do desastre de Alcácer Quibir ${ }^{172}$.

Para D. Jerónimo Osório, no seu De regis institutione et disciplina, esse ideal de sabedoria, indissociável da sua perfeição, é atingido pelo estudo da filosofia, conhecimento que abarca todos os ramos do saber e prepara o príncipe para o difícil e diversificado ofício de rei. Segundo este autor, intérprete do pensamento humanista europeu, a educação intelectual do príncipe, inseparável da sua formação moral e

${ }^{167}$ Ibidem, p. 154-155. Cf. Quintiliano, Inst. Orat., I, 1.20.

168 Ibidem, p. 152-153; p. 158-159;

${ }^{169}$ Tal como Erasmo, que insiste na Institutio principis christiani, neste método educativo (LB., IV, 564 D-565 A; 572 E-F), cf. Diogo de Teive, Ibidem, p. 134-141.

${ }^{170}$ Ibidem, p. 137-141; p. 123-125.

${ }^{171}$ Memorial das Proezas da Segunda Távola Redonda por Jorge Ferreira de Vasconcelos. Ao muyto alto e muyto poderoso rey Dom Sebastião/Primeiro deste nome em Portugal, nosso Senhor. Impressa pela primeira vez no ano de 1567. Lisboa, Typ. do Panorama, 1867, p. VII.

172 Não poderemos, no entanto, deixar de integrar a opinião deste autor numa linha temática comum a doutrinadores e moralistas. Esta temática, que surge na pena de Erasmo (Institutio principis christiani, L. B., IV, 587 D) e de Vives, e tem por objectivo contrapor às novelas de cavalaria livros de "boa doutrina", torna-se um lugar-comum ao longo do séc. XVI. Vide a este propósito, Marcel Bataillon, Erasmo y España o Estudios sobre la historia espiritual del siglo XVI. Buenos Aires, 1966, p. 622. 
religiosa, deve ser enciclopédica, semelhante à do orador na Antiguidade clássica, pois abrange todos os ramos do saber. Esta completa-se, contudo, como em Teive, pela educação física, que, nas suas múltiplas modalidades, robustece o corpo e predispõe o espírito a um desenvolvimento pleno de todas as suas faculdades.

Desta educação integral, que vai ser a tónica do humanismo renascentista, oferece-nos o modelo João de Barros - autor de escritos vários de pedagogia e didáctica - na Crónica do Imperador Clarimundo, quando nos conta que Grionesa manda "trazer da Grécia um grande filósofo, para o ensinar em todas as artes, que a tal pessoa convinham".

O papel do educador ganha então uma alta importância, pois do seu saber, das suas qualidades morais, da sua arte em moldar o espírito tenro do príncipe, vai depender o êxito ou inêxito da pátria ${ }^{173}$. Até nos príncipes, que pela sua perversidade ficaram conhecidos, a influência benéfica do mestre se fez notar. Neste termos se refere Frei Heitor Pinto, no Diálogo da Justiça, ao imperador Nero: “...verdade é que no princípio de seu império deu ele boas mostras de si, porque durava ainda nele o movimento da doutrina de seu mestre Séneca. Assim como uma roda movida com grande ímpeto, por grande espaço depois ainda que cesse o movedor, ela por si se move em virtude daquele ímpeto, que lhe pôs o braço..." ${ }^{174}$.

Em suma, a sabedoria do príncipe, que reside na sua cultura, a ascendência num passado glorioso que D. Afonso Henriques encarna ${ }^{175}$, predispõem a razão e a natureza para atingir o ideal da perfeição.

173 Todos os tratados humanistas, desde Fr. António de Beja - e mesmo os tratados de retórica - insistem no papel do educador. De registar na Institutio Sebastiani Primi de Diogo de Teive (vide ed. cit., e. g. p. 100-101; 102-103; 118- 119; 128-129) as insistentes e expressivas alusões ao papel do educador ou suas qualidades: à "modéstia, graça, humanidade /e natural brandura", / "bons costumes" /, "vida pura, e limpa" (p. 101), deve ajuntar o mestre "sabedoria, /cuidado, amor, estudo e vigilancia" (p. 129).

${ }^{174}$ Frei Heitor Pinto, Imagem da vida cristã "Diálogo da Justiça", cap. III, ed. cit., p. 153.

${ }^{175}$ Vide, e. g., D. Jerónimo Osório, De regis institutione et disciplina (Op. omnia I, 451.40 e sqq; 466.24 e sqq.). A figura de D. Afonso Henriques, associada ao milagre de Ourique, para os humanistas, móbil de orgulho nacional, pela grandeza da raça e favor divino, torna-se carismática e quase divisa dos ideais da restauração. Vide sobre este assunto, Martim de Albuquerque, A consciência nacional portuguesa. Lisboa, 1974, p. 337-348; Maria Luísa Lemos, A literatura autonomista no séc. XVII através do códice 29 da Biblioteca Geral da Universidade. Coimbra, 1985, p. 42 e sqq. 
Ele será para todos um sol, como na divisa sobreposta ao dossel do carro de Dürer. Dirá também Frei Heitor Pinto: “O bom príncipe e prelado é um sol comum a todos, que vigia sobre seu povo com muitos olhos, estando sempre no meio como o Sol que está no meio dos sete planetas" ${ }^{\text {"176 }}$.

Como está distante esta imagem da que servirá de lema a Luís XIV, o Rei Sol, do século seguinte!

Ao ganhar forma a teoria da razão de estado, também o ideal educativo humanista perde o seu verdadeiro alcance. Na verdade, quando se impõe, nos finais do séc. XVI e ao longo do séc. XVII, a teoria da razão de estado, que lança as bases de uma ciência dos costumes, sobreposta à pedagogia humanista, a noção de educação é substituída pela ciuilis disciplina ${ }^{177}$. Os valores que moldaram gerações e suas mentalidades foram alterádos ou subvertidos. Se há exaltação da virtude do príncipe, ela centra-se na prudência, vocábulo que adquire cargas semânticas até então desconhecidas dos tratados tradicionais.

Se quiséssemos apresentar uma síntese, para cada época, desde a Antiguidade aos finais do séc. XVI, das obras mais representativas do género, bastaria citarmos um número reduzido de tratados: os tratados de Isócrates, Xenofonte, Platão e Aristóteles, no século IV a. C.; a obra de Cícero; no período imperial romano, a vasta produção de Plutarco e o Panegírico de Trajano de Plínio-o-Moço, a obra de Quintiliano; no período cristão, as obras de Eusébio de Cesareia e Santo Ambrósio, a Cidade de Deus de Santo Agostinho, as Etimologiae de Santo Isidoro de Sevilha, a obra de Alcuíno na época carolíngia, a de João de Salisbúria no séc. XII, as de S. Tomás e Egídio Romano no séc. XIII, a de Marsílio de Pádua no séc. XIV, as de Pier Paolo Vergerio, Maffeo Vegio, Francesco Patrizi no séc. XV, e ao longo do séc. XVI as de Maquiavel, Erasmo, Tomás Moro, Castiglione, G. Budé, J. Osório, J. Bodin, Mariana, G. Botero.

Este século de Quinhentos, ao enfrentar a problemática que suscitaram as descobertas, as guerras de conquista e de religião, desenvolveu vários tipos de componentes ideológicas paralelas, presentes nos tratados de educação de príncipes. Estes, além de representativos de um género, dos mais antigos da literatura, são também um testemunho perfeito da história das mentalidades, documentos da

${ }^{176}$ Imagem da vida cristã, "Diálogo da Justiça", cap. V, p. 173.

177 Vide A. Stegmann, "La place de la praxis dans la motion de "raison d'état", in Théorie et pratique politiques à la Renaissance (XVII $\mathrm{e}^{\mathrm{e}}$ Colloque International de Tours), Paris, 1977, p. 496-497. 
história nacional e europeia, testemunhos das preocupações e anseios do homem, desde a Antiguidade à época moderna, verdadeiro suporte da concepção do príncipe, do retrato do governante através dos tempos.

Poderemos afirmar, em conclusão, que o retrato ideal do príncipe, a imago principis, que se impôs no humanismo renascentista, e em particular no humanismo português, é o resultado e a síntese de diferentes tendências que coexistem na época e definem o verdadeiro sentido do movimento humanista.

Neste ideal de príncipe se configurava o tipo de "homem social", criado pela civilização greco-latina, que encontrava a sua realização plena ao serviço da sociedade. Tal como na Antiguidade, a importância concedida ao saber conciliavase com a prática da vida activa, na medida em que esse saber se colocava ao serviço da comunidade. Era o ideal do rei filósofo de Platão.

Mas o príncipe humanista participava também do miles christianus, cavaleiro cristão, tal como o definira Erasmo, herdeiro directo - pelo primado da virtude sobre qualquer consideração de oportunismo político - da tradição medieval, representada nos Specula principum. Não se pode, contudo, esquecer que este universo de ecumenismo, em grande parte medieval, em que se move o princeps christianus erasmiano, se completa por uma penetrante e universal filosofia da educação, que informa o ideal de príncipe no Renascimento e o distancia do proposto pela época precedente.

É além disso por influência do ideal de cortesão, homem culto, íntegro, agradável, gracioso e requintado, que combina harmoniosamente as qualidades do espírito e do corpo e valoriza o sentido estético da existência que o príncipe perfeito do Renascimento, princeps christianus, por assim dizer se paganiza; ou, mais precisamente, se actualiza, se conforma às condições da vida contemporânea, ao ideal de urbanitas do século de ouro português e europeu e se torna modelo e paradigma de comportamentos e valores universais. 
(Página deixada propositadamente em branco) 


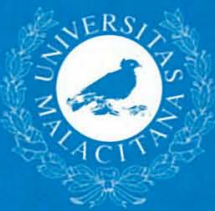

